\title{
Effect of Gibberellic Acid and Potassium Applications in Improving Salinity Tolerance of Three Rice Cultivars
}

\author{
El-Ekhtyar A.M., S.M. Bassiouni, B.B. Mikhael and W.M. Elkhoby ${ }^{1}$
}

\begin{abstract}
Two field experiments were conducted at El-Sirw Agriculture Research Station, Experimental Farm, Damietta governorate, Egypt during 2012 and 2013 summer seasons. The present investigation was designed to study the effect of gibberellic acid and potassium applications in improving salinity tolerance of three rice cultivars, namely; Giza 177, Giza 178 and Sakha 101. Data of both seasons revealed that, the three tested rice cultivars were significantly varied in their growth patterns, as well as, grain yield and its attributes. Giza 178 rice cultivar recorded the maximum values of plant height, number of tillers $/ \mathrm{m}^{2}$, chlorophyll content, leaf area index, the contents of $N, P, K$ and proline, as well as, grain yield and its attributes; viz, panicle weight and number of filled grains/panicle. However, the lowest values of the abovementioned traits were always shown with Giza 177 rice cultivar. Data, also, showed that, potassium and gibberellic acid applications could partially mitigate the harmful effects of salinity stress on growth and productivity of the three tested rice cultivars.
\end{abstract}

Key words: Rice cultivars, Salinity stress, Gibberellins and Potassium.

\section{INTRODUCTION}

Grain yield of rice depends on its genetic potential, agro-climatic conditions and various management practices (Singh and Singh, 1998). Besides, soil salinity is considered one of the most important constrain affecting rice production. In Egypt, the average of rice productivity in saline soils is much lower than that of normal soils which negatively affects the national rice production average (El-Mowafi, 1994).

Soil salinity effects plant growth and development by osmotic stress, toxic effects of $\mathrm{Na}^{+}$and $\mathrm{Cl}^{-}$ions and nutrient imbalance caused by excess of $\mathrm{Na}^{+}$and $\mathrm{Cl}^{-}$ions (Sairam and Tyagi, 2004).

In Egypt rice crop is moderately sensetive to soil salinity. However, rice cultivars discloses a wide variation in their tolerance to soil salinity (Zayed et al., 2007) such varietals variation among rice cultivars were obtained by Khan and Abdallah (2003), Kandil et al., (2010) and Zayed et al., (2012).

Gibberelline $\left(\mathrm{GA}_{3}\right)$ is a hormone induced in plants and its chemical formula is $\mathrm{C}_{19} \mathrm{H}_{22} \mathrm{O}_{6}$. The obtained favorable effect of $\mathrm{GA}_{3}$ (as growth regulator) in improving rice growth, as well as, grain yield and its components of rice under saline soil conditions might be due to its activation to $\alpha$-amylase for breakdown of stored starch during germination, enhancing IAA exertion, promoting cell elongation and division particularly, mesocotyle length and internodes of rice plants, reducing $\mathrm{Na}$ and $\mathrm{Cl}$ uptakes, increasing $\mathrm{K}, \mathrm{P}$ and $\mathrm{N}$ uptakes and chlorophyll content leading to high seedling vigor, reasonable rice growth at early and late stages, improving source-sink relation resulted in high grain yield and its components under salt stress (Chen et al., 2005 and Pan et al., 2013).

Potassium is linked with all phenomena of plant photosynthesis, respiration, metabolism of fats, carbohydrates and nitrogenous compounds, enzyme activation, cell elongation and water efficiency, so, it could be considered as a key element in rice nutrition for improving root growth and plant vigor, helping prevent lodging and enhancing rice resistance to pests and diseases (Krishnakumar et al., 2005).

The present study aimed to investigate the effect of $\mathrm{GA}_{3}$ and $\mathrm{K}_{2} \mathrm{O}$ applications, as well as, their combination treatment in improving salinity tolerance of Giza 177, Giza 178 and Sakha 101 rice cultivars.

\section{MATERIALS AND METHODS}

Two field experiments were conducted at El-Sirw Agriculture Research Station, Experimental Farm, Damietta governorate, Egypt, during 2012 and 2013 summer seasons. This investigation aimed to study the performance of three rice cultivars as affected by gibberelline and potassium applications under saline soil conditions.

The three tested rice cultivars used in this study, namely; Giza 177 (salt sensitive), Giza 178 (salt tolerant) and Sakha 101 (salt semi tolerant).

Gibberellic acid and potassium applications used in this investigation were: $\mathrm{T}_{1}$ : control (without $\mathrm{GA}_{3}$ or $\mathrm{K}_{2} \mathrm{O}$ application), $\mathrm{T}_{2}: \mathrm{GA}_{3}$ (soak rice paddy seeds in gibberellic acid solution at the concentration of 100 ppm and spray rice plants with $10 \mathrm{mg} / \mathrm{l}$ of gibberelic acid, two times at mid of tillering and panicle initiation growth stages),

\footnotetext{
${ }^{1}$ Rice Research and Training Center, Field Crops Research Institute, A.R.C., Sakha, Kafr El-Sheikh, Egypt.

Received January23, 2014, Accepted March23, 2014
} 
Table 1. Physical and chemical analysis of the experimental sites

\begin{tabular}{lcc}
\hline Character & $\mathbf{2 0 1 2}$ & $\mathbf{2 0 1 3}$ \\
\hline Physical analysis: & & \\
Sand (\%) & 15.5 & 14.5 \\
Silt (\%) & 28.3 & 30.2 \\
Clay (\%) & 56.2 & 55.3 \\
Soil texture & Clayey & Clayey \\
\hline Chemical analysis: & & \\
E.C. (ds/m) & 8.32 & 8.21 \\
Organic matter (\%) & 1.51 & 1.53 \\
pH & 8.24 & 8.16 \\
CaCO $(\%)$ & - & - \\
\hline Available N (ppm) & 96.1 & 94.6 \\
$\mathrm{P}(\mathrm{ppm})$ & 17.4 & 18.0 \\
$\mathrm{~K}(\mathrm{ppm})$ & 296.0 & 297.0 \\
$\mathrm{Fe}(\mathrm{ppm})$ & 5.06 & 5.48 \\
$\mathrm{Mn}(\mathrm{ppm})$ & 4.29 & 4.62 \\
$\mathrm{Zn}(\mathrm{ppm})$ & 0.93 & 1.07 \\
\hline
\end{tabular}

$\mathrm{T}_{3}$ : $\mathrm{K}_{2} \mathrm{O}$ (adding $45 \mathrm{~kg} \mathrm{~K} 2 \mathrm{O} /$ ha. as basal application and spry rice plants with $2 \%$ of $\mathrm{K}_{2} \mathrm{O}$ solution, two times at mid of tillering and panicle initiation growth stages) and $\mathrm{T}_{4}$ : mixed treatment $\left(\mathrm{T}_{2}+\mathrm{T}_{3}\right)$.

Soil samples were taken from the experimental site at the depth of $0-30 \mathrm{~cm}$ from the soil surface, air-dried, then, ground to pass through a two $\mathrm{mm}$ sieve and well mixed. Soil samples were physically analyzed, according to Piper (1950) and Chemically analyzed, according to Black (1983).

The previous winter crops were barley and wheat in 2012 and 2013 seasons, respectively. A strip plot-design with four replications was used. The horizontal plots were randomly devoted to the three tested rice cultivars. While, $\mathrm{GA}_{3}$ and potassium applications were randomly allocated in the vertical plots. Plot size was $16 \mathrm{~m}^{2}$ $(4 \times 4 m)$.

Sowing dates were $3^{\text {rd }}$ and $1^{\text {st }}$ May in 2012 and 2013 seasons, respectively. The rest of culture practices for inbred rice cultivation under saline soil conditions were applied, according to the Recommended cultural practices proposed by of Rice Research and Training Center of Sakha.

\section{Studied characters:}

At heading stage, five guarded hills were randomly taken from each plot to determine the following criteria:

\section{Growth parameters:}

a. Plant height $(\mathrm{cm})$.

b. Number of tillers per hill.

c. Days to heading: Number of days from sowing to $50 \%$ heading was recorded in each plot. d. Leaf chlorophyll content: It was estimated, by using Chlorophyll Analytical Apparantus, Model SPAD502 Minlota Co. Lted., Japan.

e. Flag leaf area $\left(\mathrm{cm}^{2}\right)$.

f. Leaf area index.

2. Plant N,P,K,Na and Proline Contents:

a. Potassium content: It was estimated, by using Flam Photometer, Model E.E.L., according to Jackson (1967).

b. Sodium content: It was measured, by using Flam Photometer, Model E.E.L., according to, Jackson (1967).

c. Sodium/potassium ratio: It was calculated, by using the following formula $\mathrm{Na}^{+} / \mathrm{K}^{+}$ratio $=\mathrm{Na}^{+} \% / \mathrm{K}^{+} \%$.

d. Nitrogen content: It was measured, by using Microkieldahl, according to A.O.A.C. (1970).

e. Phosphorus content: It was determined, by using Atomic Absorption Spectrophotometer, according to Jackson (1967).

f. Proline content was measured, according to the method of Bates, et al., (1973).

3. Grain yield attributes:

At harvest time, ten random main panicles from each plot were collected to determine the average values of the following characters:

a. Panicle length $(\mathrm{cm})$ : It was estimated, according to IRRI -Standard Evaluation System of Rice (1996).

b. Panicle weight (g).

c. 1000-grain weight (g).

d. Number of filled grains/panicle. 
e. Number of unfilled grains/panicle.

f. Sterility percentage: It was calculated, by using the following formula: (Number of filled grains/total number of grains) x 100 .

\section{Grain yield (t/ha):}

Rice plants in the central nine square meters of each plot were manually harvested, then, air-dried for about four days and mechanically threshed. Grain and straw yields were recorded and adjusted into tons per hectare at $14 \%$ moisture content and harvest index was calculated.

All collected data were statically analyzed, according to Gomez and Gomez (1984). Differences among treatment means were compared, according to Duncan (1955).

\section{RESULTS AND DISCUSSION}

\section{Growth patterns:}

\section{Plant height, number of tillers/hill and days to heading.}

\section{Rice cultivars performance:}

The results recorded of the three tested rice cultivars under salinity conditions revealed that, Giza 178 rice cultivar produced the tallest plants and the highest tillers number/hill (Table 2). On the other side, the lowest number of tillers/hill and days to heading were obtained by Giza 177 rice cultivar (as sensitive one).

Sakha 101 rice cultivar gave the shortest plants and recorded the longest vegetative period, but, it recorded the intermediate values of tillers number/hill. Such findings could mainly be attributed to genetic variability among rice cultivars. Similar results were reported by Sucharitha and Boopathi (2000), Kandil et al., (2010), Zayed et al., (2012) and Sumontip and Pongthai (2013).

\section{Effect of $\mathrm{GA}_{\mathbf{3}}$ and $\mathrm{K}_{\mathbf{2}} \mathrm{O}$ applications:}

Data in Table (2) clarified that, $\mathrm{GA}_{3}+\mathrm{K}_{2} \mathrm{O}$ treatment significantly recorded the tallest plants and the highest number of tillers/hill, as well as, the longest vegetative period during 2012 and 2013 seasons. While, control (without $\mathrm{GA}_{3}$ or $\mathrm{K}_{2} \mathrm{O}$ application) gave the lowest values of the abovementioned traits. In addition either $\mathrm{GA}_{3}$ or $\mathrm{K}_{2} \mathrm{O}$ treatments recorded the intermediate values in this respect. These findings could mainly be attributed to the positive effect of continuous potassium and $\mathrm{GA}_{3}$ supply until late season, whereas, $\mathrm{K}$ may be relatively increases the uptake of nitrogen, consequently extend the vegetative growth and delay panicle exertion (Hatamifar al., 2013). Beside, the role of potassium as activator of enzymes specific for a modifying internal hormone balancing (reducing ABA and increased Gibberellins and other activators concentrations) (Wang al., 2013). In addition, exogenous $\mathrm{GA}_{3}$ treatment enhanced the ability of endogenous $\mathrm{GA}_{3}$ that stimulates $\alpha$-amylase activity in germination seed by increases in formation ofglucose from starch leading to an improving in synthesis of sucrose used for seedling growth. Also, $\mathrm{GA}_{3}$ application might be reduced $\mathrm{NaCl}$ induced growth inhibition in rice in a concentration dependent manner, including the length of root tissue and influence on the abundance of same salt-regulates proteins (Fu et al., 2009).

Table 2. Effect of $\mathrm{GA}_{3}$ and $\mathrm{K}_{2} \mathrm{O}$ applications on plant height, number of ttillers/hill and days to heading of three rice cultivars under saline soil conditions

\begin{tabular}{|c|c|c|c|c|c|c|}
\hline \multirow[t]{2}{*}{ Treatments } & \multicolumn{2}{|c|}{ Plant height (cm) } & \multicolumn{2}{|c|}{$\begin{array}{c}\text { Number of } \\
\text { tillers/hill }\end{array}$} & \multicolumn{2}{|c|}{$\begin{array}{l}\text { Days to heading } \\
\text { (Days after sowing) }\end{array}$} \\
\hline & 2012 & 2013 & 2012 & 2013 & 2012 & 2013 \\
\hline \multicolumn{7}{|l|}{ Rice cultivar $(\mathrm{C})$ : } \\
\hline Giza 177 & $74.86 b$ & $76.36 b$ & $13.6 \mathrm{c}$ & $14.0 \mathrm{c}$ & $83.6 \mathrm{c}$ & $85.4 \mathrm{c}$ \\
\hline Giza 178 & $79.62 \mathrm{a}$ & $78.93 a$ & $18.2 \mathrm{a}$ & $17.4 \mathrm{a}$ & $91.78 b$ & $91.2 b$ \\
\hline Sakha 101 & $67.25 \mathrm{c}$ & $70.98 \mathrm{c}$ & $15.8 \mathrm{~b}$ & $15.6 \mathrm{~b}$ & $94.03 \mathrm{a}$ & $94.7 \mathrm{a}$ \\
\hline F. Test & $* *$ & $* *$ & $* *$ & $* *$ & $* *$ & $* *$ \\
\hline \multicolumn{7}{|l|}{$\mathrm{GA}_{3}$ and $\mathrm{K}_{2} \mathrm{O}$ applications $(\mathrm{F})$ : } \\
\hline $\mathrm{T}_{1}:$ Control & $65.92 d$ & $67.28 \mathrm{~d}$ & $13.1 \mathrm{c}$ & $12.7 \mathrm{c}$ & $85.70 d$ & $86.23 \mathrm{c}$ \\
\hline $\mathrm{T}_{2}: \mathrm{GA}_{3}$ & $74.97 b$ & $76.14 b$ & $16.9 \mathrm{a}$ & $16.7 \mathrm{ab}$ & $91.30 \mathrm{~b}$ & $90.87 b$ \\
\hline $\mathrm{T}_{3}: \mathrm{K}_{2} \mathrm{O}$ & $70.18 \mathrm{c}$ & $71.67 \mathrm{c}$ & $15.6 b$ & $16.0 \mathrm{~b}$ & $89.40 \mathrm{c}$ & $90.63 b$ \\
\hline $\mathrm{T}_{4}: \mathrm{GA}_{3}+\mathrm{K}_{2} \mathrm{O}$ & $84.56 \mathrm{a}$ & $86.60 \mathrm{a}$ & $17.7 \mathrm{a}$ & $17.3 \mathrm{a}$ & $92.80 \mathrm{a}$ & $94.0 \mathrm{a}$ \\
\hline F. Test & $* *$ & $* *$ & $* *$ & $* *$ & $* *$ & $* *$ \\
\hline CxF Interaction: & $* *$ & $* *$ & N.S & N.S & $* *$ & $* *$ \\
\hline
\end{tabular}

E.C. $=8.32$ and $8.21 \mathrm{ds} / \mathrm{m}$ in 2012 and 2013 seasons, respectively.

Means: followed by the same litter (s) are not significantly different, according to DMRT.

*** and N.S.: Significant at 0.05 and 0.01 levels and not significant, respectively. 

Similar findings are in harmony with those reported by Meena et al. (2003), Sundari and Sureshkumar (2004), Zayed et al. (2006), Sivakumar et al., (2007), Manzoor et al. (2008), Abd El-Hamed (2013) and Sumontip and Pongthai (2013).

\section{Effect of the interaction:}

The interaction between $\mathrm{GA}_{3}$ and $\mathrm{K}_{2} \mathrm{O}$ applications ,as well as, rice cultivars had highly significant effect on plant height and number of days to heading. At the application of $\mathrm{T}_{4}$ treatment Giza 178 rice cultivar produced the tallest plants followed by Giza 177 and Sakha 101 rice cultivars. Moreover, all tested rice cultivars recorded the tallest plants when the mixed treatment $\left(\mathrm{GA}_{3}+\mathrm{K}_{2} \mathrm{O}\right)$ was applied (Table, 3).In addition, the longest vegetative period during both seasons was recorded by Sakha 101 rice cultivar with $\mathrm{GA}_{3}+\mathrm{K}_{2} \mathrm{O}$ treatment $\left(\mathrm{T}_{4}\right)$, while, Giza 177 rice cultivar without potassium or gibberellic acid application recorded the shortest vegetative period (Table, 4). On the other hand, number of tillers/hill was not significantly affected by the interaction.

\section{Leaf chlorophyll content, flag leaf area and leaf} area index.

Rice cultivars performance:

It is clear from data tabulated in Table (5) that, there were significant differences among the tested rice cultivars for leaf chlorophyll content and flag leaf area, whereas, the differences among three tested rice cultivars in leaf area index were insignificant. During both seasons the maximum values of leaf chlorophyll content and flag leaf area were produced by Giza 178 and Sakha 101 rice cultivars, respectively. On the contrary, Giza 177 rice cultivar gave the lowest values in the abovementioned traits. This variation in leaf chlorophyll content and flag leaf area of the three tested rice cultivars could be mainly due to their genetic make up. Such varietals' differences among rice cultivars under saline soil conditions have been pointed out by Zayed et al. (2006), Farooq et al., (2008), Okasha,Amira (2011) and Sumontip and Pongthai (2013).

\section{Effect of $\mathrm{GA}_{3}$ and $\mathrm{K}_{2} \mathrm{O}$ applications:}

Results in Table (5) indicated a positive effect on leaf chlorophyll content and flag leaf area in both seasons of study. The maximum values of leaf chlorophyll content, as well as, the largest flag leaf and the highest leaf area index were obtained when $\mathrm{GA}_{3}$ and $\mathrm{K}_{2} \mathrm{O}$ were applied $\left(\mathrm{T}_{4}\right)$. On the other hand, control $\left(\mathrm{T}_{1}\right)$ recorded the lowest values. Both $\mathrm{GA}_{3}\left(\mathrm{~T}_{2}\right)$ and $\mathrm{K}_{2} \mathrm{O}\left(\mathrm{T}_{3}\right)$ treatments gave intermediate values in this respect. Enhancing leaf growth of rice grown under saline soil conditions by $\mathrm{GA}_{3}+\mathrm{K}_{2} \mathrm{O}$ treatment could be mainly due to the superiority of the integration between soil and foliar potassium and gibberellic acid application

Table 3. Effect of the interaction between $\mathrm{GA}_{3}$ and $\mathrm{K}_{2} \mathrm{O}$ applications, as well as, rice cultivars on plant height $(\mathrm{cm})$ under saline soil conditions

\begin{tabular}{ccccccc}
\hline \multirow{2}{*}{$\mathbf{G A}_{3}$ and $\mathbf{K}_{\mathbf{2}} \mathbf{O}$ applications $(\mathbf{F})$} & \multicolumn{5}{c}{ Rice cultivars $(\mathbf{C})$} \\
\cline { 2 - 7 } & \multicolumn{3}{c}{$\mathbf{2 0 1 2}$} & \multicolumn{3}{c}{$\mathbf{2 0 1 3}$} \\
\cline { 2 - 6 } & Giza 177 & Giza 178 & Sakha 101 & Giza 177 & Giza 178 & Sakha 101 \\
\hline $\mathrm{T}_{1}:$ Control & $66.53 \mathrm{ef}$ & $67.82 \mathrm{e}$ & $63.41 \mathrm{~g}$ & $67.94 \mathrm{f}$ & $68.18 \mathrm{f}$ & $65.72 \mathrm{~g}$ \\
$\mathrm{~T}_{2}: \mathrm{GA}_{3}$ & $75.89 \mathrm{c}$ & $84.06 \mathrm{~b}$ & $64.97 \mathrm{fg}$ & $77.25 \mathrm{~d}$ & $82.74 \mathrm{c}$ & $68.43 \mathrm{f}$ \\
$\mathrm{T}_{3}: \mathrm{K}_{2} \mathrm{O}$ & $72.24 \mathrm{~d}$ & $75.12 \mathrm{c}$ & $63.18 \mathrm{~g}$ & $73.86 \mathrm{e}$ & $74.23 \mathrm{e}$ & $66.93 \mathrm{fg}$ \\
$\mathrm{T}_{4}: \mathrm{GA}_{3}+\mathrm{K}_{2} \mathrm{O}$ & $84.77 \mathrm{~b}$ & $91.48 \mathrm{a}$ & $77.43 \mathrm{c}$ & $86.37 \mathrm{~b}$ & $90.57 \mathrm{a}$ & $82.86 \mathrm{c}$ \\
\hline
\end{tabular}

E.C. $=8.32$ and $8.21 \mathrm{ds} / \mathrm{m}$ in 2012 and 2013 seasons, respectively.

Means: followed by the same litter (s) are not significantly different, according to DMRT.

Table 4. Effect of the interaction between $\mathrm{GA}_{3}$ and $\mathrm{K}_{2} \mathrm{O}$ applications, as well as, rice cultivars on number of days to heading (days after sowing) under saline soil conditions.

\begin{tabular}{lcccccc}
\hline \multirow{2}{*}{$\mathbf{G A}_{3}$ and $\mathbf{K}_{2} \mathbf{O}$ applications $(\mathbf{F})$} & \multicolumn{5}{c}{ Rice cultivars $(\mathbf{C})$} \\
\cline { 2 - 7 } & \multicolumn{3}{c}{$\mathbf{2 0 1 2}$} & \multicolumn{4}{c}{$\mathbf{2 0 1 3}$} \\
\cline { 2 - 6 } & Giza 177 & Giza 178 & Sakha 101 & Giza 177 & Giza 178 & Sakha 101 \\
\hline $\mathrm{T}_{1}:$ Control & $80.9 \mathrm{j}$ & $87.2 \mathrm{f}$ & $89.0 \mathrm{e}$ & $81.2 \mathrm{j}$ & $88.1 \mathrm{~g}$ & $89.4 \mathrm{f}$ \\
$\mathrm{T}_{2}: \mathrm{GA}_{3}$ & $83.3 \mathrm{i}$ & $93.8 \mathrm{c}$ & $96.8 \mathrm{~b}$ & $84.9 \mathrm{i}$ & $92.2 \mathrm{~d}$ & $95.5 \mathrm{~b}$ \\
$\mathrm{~T}_{3}: \mathrm{K}_{2} \mathrm{O}$ & $84.5 \mathrm{~h}$ & $91.6 \mathrm{~d}$ & $92.1 \mathrm{~d}$ & $92.2 \mathrm{~d}$ & $91.0 \mathrm{e}$ & $94.1 \mathrm{c}$ \\
$\mathrm{T}_{4}: \mathrm{GA}_{3}+\mathrm{K}_{2} \mathrm{O}$ & $85.7 \mathrm{~g}$ & $94.5 \mathrm{c}$ & $98.2 \mathrm{a}$ & $95.5 \mathrm{~b}$ & $93.5 \mathrm{c}$ & $99.8 \mathrm{a}$ \\
\hline
\end{tabular}

E.C. $=8.32$ and $8.21 \mathrm{ds} / \mathrm{m}$ in 2012 and 2013 seasons, respectively.

Means: followed by the same litter (s) are not significantly different, according to DMRT. 
Table 5. Effect of $\mathrm{GA}_{3}$ and $\mathrm{K}_{2} \mathrm{O}$ applications on leaf chlorophyll content, flag leaf area and leaf area index of three rice cultivars under saline soil conditions

\begin{tabular}{|c|c|c|c|c|c|c|}
\hline \multirow[t]{2}{*}{ Treatments } & \multicolumn{2}{|c|}{$\begin{array}{c}\text { Leaf chlorophyll } \\
\text { content (SPAD value) }\end{array}$} & \multicolumn{2}{|c|}{ Flag leaf area $\left(\mathrm{cm}^{2}\right)$} & \multicolumn{2}{|c|}{ Leaf area index } \\
\hline & 2012 & 2013 & 2012 & 2013 & 2012 & 2013 \\
\hline \multicolumn{7}{|l|}{ Rice cultivar $(\mathrm{C})$ : } \\
\hline Giza 177 & $32.72 b$ & $31.55 \mathrm{c}$ & $17.46 \mathrm{c}$ & $18.24 \mathrm{c}$ & 5.78 & 5.62 \\
\hline Giza 178 & $36.53 \mathrm{a}$ & $34.92 \mathrm{a}$ & $24.83 b$ & $24.97 b$ & 5.86 & 5.69 \\
\hline Sakha 101 & $34.95 \mathrm{~b}$ & $33.47 \mathrm{~b}$ & $32.17 \mathrm{a}$ & $33.36 \mathrm{a}$ & 5.51 & 5.35 \\
\hline F. Test & $* *$ & $* *$ & $* *$ & $* *$ & N.S & N.S \\
\hline \multicolumn{7}{|c|}{$\mathrm{GA}_{3}$ and $\mathrm{K}_{2} \mathrm{O}$ applications $(\mathrm{F})$ : } \\
\hline $\mathrm{T}_{1}:$ Control & $29.66 \mathrm{~d}$ & $28.56 \mathrm{c}$ & $22.51 \mathrm{~d}$ & $23.37 \mathrm{~d}$ & $5.38 \mathrm{c}$ & $5.29 b$ \\
\hline $\mathrm{T}_{2}: \mathrm{GA}_{3}$ & $36.08 b$ & $34.35 b$ & $23.14 \mathrm{c}$ & $24.11 \mathrm{c}$ & $5.84 \mathrm{ab}$ & $5.67 \mathrm{a}$ \\
\hline $\mathrm{T}_{3}: \mathrm{K}_{2} \mathrm{O}$ & $35.22 \mathrm{c}$ & $33.81 b$ & $26.45 b$ & $26.53 b$ & $5.65 \mathrm{bc}$ & $5.53 \mathrm{ab}$ \\
\hline $\mathrm{T}_{4}: \mathrm{GA}_{3}+\mathrm{K}_{2} \mathrm{O}$ & $37.97 \mathrm{a}$ & $36.52 \mathrm{a}$ & $27.18 \mathrm{a}$ & $28.08 \mathrm{a}$ & $5.99 \mathrm{a}$ & $5.72 \mathrm{a}$ \\
\hline F. Test & $*$ & $* *$ & $* *$ & $* *$ & $*$ & $*$ \\
\hline CxF Interaction: & $* *$ & $* *$ & $* *$ & $* *$ & N.S & N.S \\
\hline
\end{tabular}

E.C. $=8.32$ and $8.21 \mathrm{ds} / \mathrm{m}$ in 2012 and 2013 seasons, respectively.

Means: followed by the same litter (s) are not significantly different, according to DMRT.

$*$,** and N.S.: Significant at 0.05 and 0.01 levels and not significant, respectively.

during critical crop growth stages resulted in increasing plant $\mathrm{K}$ content, which considered co-activator of enzymes related to chlorophyll biosynthesis formation.Also, $\mathrm{K}$ might be relatively increased the uptake of nitrogen, consequently extend the vegetative growth. Moreover, $\mathrm{GA}_{3}$ application encouraged growth of rice leaves due to its role in cell elongation and division which increase photosynthetic activity (Wang et al., 2013). These findings are in line with those reported by Wang et al. (2002), Dong et al. (2008) and Hagras et al., (2011).

\section{Effect of the interaction:}

Tables (6 and 7) showed that, when potassium fertilizer and gibberellic acid were added (the mixed treatment), Giza 178 rice cultivar produced its maximum values of leaf chlorophyll content and Sakha 101 rice cultivar gave its largest flag leaves, while the narrowest flag leaf and the lowest values of leaf chlorophyll content were obtained by Giza 177 rice cultivar with the control.

\section{II.Plant N, P, K, Na, and Proline contents:}

1. potassium (\%), sodium (\%) and sodium / potassium ratio.

\section{Rice cultivars performance:}

Data of table (8) indicated that, the three tested rice cultivars were significantly varied in their $\mathrm{K}$ and $\mathrm{Na}$ percentages, as well as, $\mathrm{Na}^{+} / \mathrm{K}^{+}$ratio during 2012 and 2013 seasons. The maximum potassium percentage was obtained by Giza 178 rice cultivar. The differences between Sakha 101 and Giza 177 rice cultivars in potassium percentage during two seasons were insignificant. Meanwhile, Giza 177 rice gave the maximum sodium percentage with no significant differences with Sakha 101. On the contrast, Giza 177 rice cultivar recorded the maximum $\mathrm{Na}^{+} / \mathrm{K}^{+}$ratio. These varietals' variation among these tested rice cultivars could mainly be due to their genetic background and their variation in ions selectivity. In addition Giza 178 rice cultivar had high affinity for ion selectivity, which reduces sodium uptake and increases uptake leading to a low $\mathrm{Na}^{+} / \mathrm{K}^{+}$ratio (Zayed et al., 2007). Such findings were reported by Khan and Abdallah (2003) and Abd ElHamed (2013).

\section{Effect of $\mathrm{GA}_{3}$ and $\mathrm{K}_{2} \mathrm{O}$ applications:}

Gibberellic acid and potassium applications significantly affected plant $\mathrm{K}, \mathrm{Na}$ and $\mathrm{Na}^{+} / \mathrm{K}^{+}$ratio during both seasons of study (Table 8). The mixed treatment of $\mathrm{GA}_{3}+\mathrm{K}_{2} \mathrm{O}$ significantly gave the highest percentages of $\mathrm{K}$ and $\mathrm{Na}$. On the other side, the lowest contents $\mathrm{K}$ and $\mathrm{Na}$ were obtained by control (without $\mathrm{GA}_{3}$ or $\mathrm{K}_{2} \mathrm{O}$ application). While, both $\mathrm{GA}_{3}$ or $\mathrm{K}_{2} \mathrm{O}$ treatments came in between. The highest potassium/sodium ratio was recorded with control treatment $\left(\mathrm{T}_{1}\right)$. In addition, growth regulator treatment $\left(T_{2}\right)$ and nutrient treatment $\left(T_{3}\right)$ or their combination treatment $\left(\mathrm{T}_{4}\right)$ significantly decreased $\mathrm{Na}^{+} / \mathrm{K}^{+}$ratio. The Superiority of $\mathrm{GA}_{3}+\mathrm{K}_{2} \mathrm{O}$ treatment $\left(\mathrm{T}_{4}\right)$ in increasing $\mathrm{K}$ and $\mathrm{Na}$, as well as, reducing $\mathrm{Na}^{+} / \mathrm{K}^{+}$ratio under salinity stress could be mainly attributed to the positive effect of $\mathrm{GA}_{3}$ and $\mathrm{K}_{2} \mathrm{O}$ in enhancing nutrients absorption and translocation by rice plants(Wang et al., 2013). The current findings are in coincidence with those reported by Baskar et al.,(2000),Hong and Wang 
(2004), Pandey et al., (2007), Reddy et al., (2009),

Bassiouni et al., (2011), and Zayed (2012).

Table 6. Effect of the interaction between $\mathrm{GA}_{3}$ and $\mathrm{K}_{2} \mathrm{O}$ applications, as well as, rice cultivars on leaf chlorophyll content (SPAD value) under saline soil conditions

\begin{tabular}{lccccccc}
\hline \multirow{2}{*}{$\mathbf{G A}_{3}$ and $\mathbf{K}_{\mathbf{2}} \mathbf{O}$ applications $(\mathbf{F})$} & \multicolumn{5}{c}{ Rice cultivars (C) } \\
\cline { 2 - 7 } & \multicolumn{5}{c}{$\mathbf{2 0 1 2}$} & \multicolumn{5}{c}{$\mathbf{2 0 1 3}$} \\
\cline { 2 - 7 } & Giza 177 & Giza 178 & Sakha 101 & Giza 177 & Giza 178 & Sakha 101 \\
\hline $\mathrm{T}_{1}:$ Control & $27.04 \mathrm{f}$ & $31.18 \mathrm{e}$ & $30.76 \mathrm{e}$ & $26.87 \mathrm{~h}$ & $30.39 \mathrm{fg}$ & $28.43 \mathrm{gh}$ \\
$\mathrm{T}_{2}: \mathrm{GA}_{3}$ & $34.23 \mathrm{~d}$ & $37.24 \mathrm{~b}$ & $36.17 \mathrm{c}$ & $33.03 \mathrm{de}$ & $35.73 \mathrm{bc}$ & $34.29 \mathrm{~cd}$ \\
$\mathrm{~T}_{3}: \mathrm{K}_{2} \mathrm{O}$ & $33.54 \mathrm{~d}$ & $37.96 \mathrm{~b}$ & $34.16 \mathrm{~d}$ & $31.83 \mathrm{ef}$ & $35.49 \mathrm{bc}$ & $34.11 \mathrm{~cd}$ \\
$\mathrm{~T}_{4}: \mathrm{GA}_{3}+\mathrm{K}_{2} \mathrm{O}$ & $36.07 \mathrm{c}$ & $39.13 \mathrm{a}$ & $38.71 \mathrm{ab}$ & $34.45 \mathrm{~cd}$ & $38.08 \mathrm{a}$ & $37.03 \mathrm{ab}$ \\
\hline
\end{tabular}

E.C. $=8.32$ and $8.21 \mathrm{ds} / \mathrm{m}$ in 2012 and 2013 seasons, respectively.

Means: followed by the same litter ( $\mathrm{s}$ ) are not significantly different, according to DMRT.

Table 7. Effect of the interaction between $\mathrm{GA}_{3}$ and $\mathrm{K}_{2} \mathrm{O}$ applications, as well as, rice cultivars on flag leaf area $\left(\mathrm{cm}^{2}\right)$ of three rice cultivars under saline soil conditions

\begin{tabular}{lcccccc}
\hline \multirow{2}{*}{$\mathbf{G A}_{\mathbf{3}}$ and $\mathbf{K}_{\mathbf{2}} \mathbf{O}$ applications $(\mathbf{F})$} & \multicolumn{5}{c}{ Rice cultivars $(\mathbf{C})$} \\
\cline { 2 - 7 } & \multicolumn{3}{c}{$\mathbf{2 0 1 2}$} & \multicolumn{3}{c}{$\mathbf{2 0 1 3}$} \\
\cline { 2 - 6 } & Giza 177 & Giza 178 & Sakha 101 & Giza177 & Giza178 & Sakha 101 \\
\hline $\mathrm{T}_{1}:$ Control & $15.89 \mathrm{~h}$ & $22.82 \mathrm{f}$ & $28.81 \mathrm{~d}$ & $16.66 \mathrm{i}$ & $22.79 \mathrm{~g}$ & $30.67 \mathrm{~d}$ \\
$\mathrm{~T}_{2}: \mathrm{GA}_{3}$ & $16.40 \mathrm{~h}$ & $23.27 \mathrm{f}$ & $29.74 \mathrm{c}$ & $16.96 \mathrm{i}$ & $23.65 \mathrm{~g}$ & $31.72 \mathrm{c}$ \\
$\mathrm{T}_{3}: \mathrm{K}_{2} \mathrm{O}$ & $18.58 \mathrm{~g}$ & $26.32 \mathrm{e}$ & $34.45 \mathrm{~b}$ & $19.32 \mathrm{~h}$ & $26.06 \mathrm{f}$ & $34.21 \mathrm{~b}$ \\
$\mathrm{~T}_{4}: \mathrm{GA}_{3}+\mathrm{K}_{2} \mathrm{O}$ & $18.95 \mathrm{~g}$ & $26.91 \mathrm{e}$ & $35.68 \mathrm{a}$ & $20.03 \mathrm{~h}$ & $27.38 \mathrm{e}$ & $36.84 \mathrm{a}$ \\
\hline
\end{tabular}

E.C. $=8.32$ and $8.21 \mathrm{ds} / \mathrm{m}$ in 2012 and 2013 seasons, respectively.

Means: followed by the same litter (s) are not significantly different, according to DMRT.

Table 8. Effect of $\mathrm{GA}_{3}$ and $\mathrm{K}_{2} \mathrm{O}$ applications on $\mathrm{K}(\%)$, $\mathrm{Na}(\%)$ and $\mathrm{Na}^{+} / \mathrm{K}^{+}$ratio of three rice cultivars under saline soil conditions

\begin{tabular}{lcccccc}
\hline \multirow{2}{*}{ Treatments } & \multicolumn{2}{c}{$\mathbf{K}(\mathbf{\%})$} & \multicolumn{2}{c}{$\mathbf{N a}(\mathbf{\%})$} & \multicolumn{2}{c}{$\mathbf{N a}^{+} / \mathbf{K}^{+}$ratio } \\
\cline { 2 - 8 } & $\mathbf{2 0 1 2}$ & $\mathbf{2 0 1 3}$ & $\mathbf{2 0 1 2}$ & $\mathbf{2 0 1 3}$ & $\mathbf{2 0 1 2}$ & $\mathbf{2 0 1 3}$ \\
\hline Rice cultivar $(\mathrm{C}):$ & & & & & & \\
Giza 177 & $1.62 \mathrm{~b}$ & $1.85 \mathrm{~b}$ & $0.559 \mathrm{a}$ & $0.545 \mathrm{a}$ & $0.368 \mathrm{a}$ & $0.313 \mathrm{a}$ \\
Giza 178 & $2.03 \mathrm{a}$ & $2.21 \mathrm{a}$ & $0.520 \mathrm{~b}$ & $0.519 \mathrm{~b}$ & $0.263 \mathrm{c}$ & $0.238 \mathrm{c}$ \\
Sakha 101 & $1.79 \mathrm{~b}$ & $1.92 \mathrm{~b}$ & $0.545 \mathrm{a}$ & $0.533 \mathrm{ab}$ & $0.316 \mathrm{~b}$ & $0.293 \mathrm{~b}$ \\
\hline $\mathrm{F}$ Test & $* *$ & $* *$ & $* *$ & $* *$ & $* *$ & $* *$ \\
\hline $\mathrm{GA}_{3}$ and $\mathrm{K}_{2} \mathrm{O}$ applications (F): & & & & & & \\
$\mathrm{T}_{1}:$ Control & $1.34 \mathrm{c}$ & $1.42 \mathrm{~d}$ & $0.518 \mathrm{c}$ & $0.516 \mathrm{~b}$ & $0.409 \mathrm{a}$ & $0.378 \mathrm{a}$ \\
$\mathrm{T}_{2}: \mathrm{GA}_{3}$ & $1.81 \mathrm{~b}$ & $2.06 \mathrm{c}$ & $0.548 \mathrm{ab}$ & $0.539 \mathrm{a}$ & $0.307 \mathrm{~b}$ & $0.263 \mathrm{~b}$ \\
$\mathrm{~T}_{3}: \mathrm{K}_{2} \mathrm{O}$ & $1.97 \mathrm{ab}$ & $2.18 \mathrm{~b}$ & $0.529 \mathrm{bc}$ & $0.529 \mathrm{ab}$ & $0.273 \mathrm{bc}$ & $0.247 \mathrm{c}$ \\
$\mathrm{T}_{4}: \mathrm{GA}_{3}+\mathrm{K}_{2} \mathrm{O}$ & $2.12 \mathrm{a}$ & $2.31 \mathrm{a}$ & $0.570 \mathrm{a}$ & $0.545 \mathrm{a}$ & $0.271 \mathrm{c}$ & $0.236 \mathrm{c}$ \\
\hline $\mathrm{F}$ Test & $* *$ & $* *$ & $* *$ & $* *$ & $* *$ & $* *$ \\
\hline CxF Interaction: & $*$ & $* *$ & N.S & N.S & $*$ & $* *$
\end{tabular}

E.C. $=8.32$ and $8.21 \mathrm{ds} / \mathrm{m}$ in 2012 and 2013 seasons, respectively.

Means: followed by the same litter ( $\mathrm{s}$ ) are not significantly different, according to DMRT.

*** and N.S.: Significant at 0.05 and 0.01 levels and not significant, respectively.

\section{Effect of the interaction:}

Table (8) showed that, both potassium content and sodium/potassium ratio were significantly affected by the interaction between $\mathrm{GA}_{3}$ and $\mathrm{K}_{2} \mathrm{O}$ applications , as well as, rice cultivars in both seasons of study. The maximum potassium percentage were produced by Giza 178 rice cultivar when it treated with $\mathrm{K}_{2} \mathrm{O}$ or with the mixed treatment of $\left(\mathrm{GA}_{3}+\mathrm{K}_{2} \mathrm{O}\right)$ without any significant difference between them. In contrast, the lowest potassium content was obtained by Giza 177 rice cultivar with control (without $\mathrm{GA}_{3}$ or $\mathrm{K}_{2} \mathrm{O}$ application) (Table 9).It is clear from data presented in Table (10) that, the lowest $\mathrm{Na}^{+} / \mathrm{K}^{+}$ratio was recorded by Giza 178 rice cultivar when it treated with the mixed treatment $\left(\mathrm{GA}_{3}+\mathrm{K}_{2} \mathrm{O}\right)$ or with $\mathrm{K}_{2} \mathrm{O}$ alone, while, the highest 
$\mathrm{Na}^{+} / \mathrm{K}^{+}$ratio was recorded by Giza 177 rice cultivar with the control (without $\mathrm{GA}_{3}$ and $\mathrm{K}_{2} \mathrm{O}$ application).

2. Nitrogen, phosphorus and proline percentages.

Rice cultivars performance:

Data of table (11) indicated that, the three tested rice cultivars were significantly varied in their N, P and Proline percentages during 2012 and 2013 seasons. Giza 178 rice cultivar gave the maximum phosphorus, and proline percentage. Meanwhile, Sakha 101 rice cultivar recorded the highest nitrogen percentage without any significant difference with Giza 178 rice

Table 9. Effect of the interaction between $\mathrm{GA}_{3}$ and $\mathrm{K}_{2} \mathrm{O}$ applications, as well as, rice cultivars on potassium percentage under saline soil conditions

\begin{tabular}{lcccccc}
\hline \multirow{2}{*}{$\mathbf{G A}_{\mathbf{3}}$ and $\mathbf{K}_{2} \mathbf{O}$ applications $(\mathbf{F})$} & \multicolumn{5}{c}{ Rice cultivars $(\mathbf{C})$} \\
\cline { 2 - 7 } & \multicolumn{5}{c}{$\mathbf{2 0 1 2}$} & \multicolumn{4}{c}{$\mathbf{2 0 1 3}$} \\
\cline { 2 - 7 } & Giza 177 & Giza 178 & Sakha 101 & Giza 177 & Giza 178 & Sakha 101 \\
\hline $\mathrm{T}_{1}:$ Control & $2.77 \mathrm{f}$ & $3.34 \mathrm{de}$ & $3.16 \mathrm{e}$ & $2.92 \mathrm{f}$ & $3.56 \mathrm{e}$ & $3.03 \mathrm{f}$ \\
$\mathrm{T}_{2}: \mathrm{GA}_{3}$ & $3.56 \mathrm{~cd}$ & $3.74 \mathrm{bc}$ & $3.38 \mathrm{de}$ & $3.88 \mathrm{~d}$ & $3.94 \mathrm{~cd}$ & $3.61 \mathrm{e}$ \\
$\mathrm{T}_{3}: \mathrm{K}_{2} \mathrm{O}$ & $3.42 \mathrm{de}$ & $3.96 \mathrm{ab}$ & $3.78 \mathrm{bc}$ & $3.62 \mathrm{e}$ & $4.18 \mathrm{a}$ & $3.99 \mathrm{bcd}$ \\
$\mathrm{T}_{4}: \mathrm{GA}_{3}+\mathrm{K}_{2} \mathrm{O}$ & $3.71 \mathrm{bc}$ & $4.08 \mathrm{a}$ & $3.85 \mathrm{ab}$ & $3.98 \mathrm{~cd}$ & $4.15 \mathrm{ab}$ & $4.05 \mathrm{abc}$ \\
\hline
\end{tabular}

E.C. $=8.32$ and $8.21 \mathrm{ds} / \mathrm{m}$ in 2012 and 2013 seasons, respectively.

Means: followed by the same litter (s) are not significantly different, according to DMRT.

Table 10. Effect of the interaction between $\mathrm{GA}_{3}$ and $\mathrm{K}_{2} \mathrm{O}$ applications, as well as, rice cultivars on sodium/potassium ratio of three rice cultivars under saline soil conditions

\begin{tabular}{lcccccc}
\hline \multirow{2}{*}{$\mathbf{G A}_{3}$ and $\mathbf{K}_{\mathbf{2}} \mathbf{O}$ applications $(\mathbf{F})$} & \multicolumn{5}{c}{ Rice cultivars $(\mathbf{C})$} \\
\cline { 2 - 7 } & \multicolumn{3}{c}{$\mathbf{2 0 1 2}$} & \multicolumn{3}{c}{$\mathbf{2 0 1 3}$} \\
\cline { 2 - 7 } & Giza 177 & Giza 178 & Sakha 101 & Giza 177 & Giza 178 & Sakha 101 \\
\hline $\mathrm{T}_{1}:$ Control & $0.522 \mathrm{a}$ & $0.317 \mathrm{cde}$ & $0.387 \mathrm{~b}$ & $0.451 \mathrm{a}$ & $0.280 \mathrm{~cd}$ & $0.405 \mathrm{~b}$ \\
$\mathrm{~T}_{2}: \mathrm{GA}_{3}$ & $0.311 \mathrm{cde}$ & $0.266 \mathrm{ef}$ & $0.345 \mathrm{bc}$ & $0.259 \mathrm{de}$ & $0.238 \mathrm{ef}$ & $0.292 \mathrm{c}$ \\
$\mathrm{T}_{3}: \mathrm{K}_{2} \mathrm{O}$ & $0.329 \mathrm{bcd}$ & $0.233 \mathrm{f}$ & $0.258 \mathrm{ef}$ & $0.292 \mathrm{c}$ & $0.213 \mathrm{f}$ & $0.236 \mathrm{ef}$ \\
$\mathrm{T}_{4}: \mathrm{GA}_{3}+\mathrm{K}_{2} \mathrm{O}$ & $0.308 \mathrm{cde}$ & $0.234 \mathrm{f}$ & $0.272 \mathrm{def}$ & $0.251 \mathrm{e}$ & $0.221 \mathrm{f}$ & $0.237 \mathrm{ef}$ \\
\hline
\end{tabular}

E.C. $=8.32$ and $8.21 \mathrm{ds} / \mathrm{m}$ in 2012 and 2013 seasons, respectively.

Means: followed by the same litter (s) are not significantly different, according to DMRT.

Table 11. Effect of $\mathrm{GA}_{3}$ and $\mathrm{K}_{2} \mathrm{O}$ applications on nitrogen, phosphorus and proline percentages of three rice cultivars under saline soil conditions

\begin{tabular}{|c|c|c|c|c|c|c|}
\hline \multirow[t]{2}{*}{ Treatments } & \multicolumn{2}{|c|}{$\mathbf{N}(\%)$} & \multicolumn{2}{|c|}{$\mathbf{P}(\%)$} & \multicolumn{2}{|c|}{$\begin{array}{c}\text { Free Proline } \\
\mu \text { moles/g/ fresh wight }\end{array}$} \\
\hline & 2012 & 2013 & 2012 & 2013 & 2012 & 2013 \\
\hline \multicolumn{7}{|l|}{ Rice cultivar (C): } \\
\hline Giza 177 & $2.29 b$ & $2.33 b$ & $0.317 \mathrm{a}$ & $0.323 \mathrm{a}$ & $0.49 \mathrm{c}$ & $0.50 \mathrm{c}$ \\
\hline Giza 178 & $2.43 \mathrm{a}$ & $2.52 \mathrm{a}$ & $0.309 \mathrm{ab}$ & $0.317 \mathrm{a}$ & $0.62 \mathrm{a}$ & $0.64 \mathrm{a}$ \\
\hline Sakha 101 & $2.49 \mathrm{a}$ & $2.57 \mathrm{a}$ & $0.283 \mathrm{~b}$ & $0.274 b$ & $0.57 \mathrm{~b}$ & $0.59 \mathrm{~b}$ \\
\hline F. Test & $* *$ & $* *$ & $*$ & $* *$ & $* *$ & $* *$ \\
\hline $\mathrm{GA}_{3}$ and $\mathrm{K}_{2} \mathrm{O}$ applications $(\mathrm{F})$ : & $2.09 \mathrm{c}$ & $2.12 \mathrm{c}$ & $0.294 b$ & $0.281 \mathrm{c}$ & $0.44 d$ & $0.46 \mathrm{~d}$ \\
\hline $\mathrm{I}_{1}:$ Control & $2.56 \mathrm{a}$ & $2.59 \mathrm{ab}$ & $0.291 b$ & $0.298 b$ & $0.52 \mathrm{c}$ & $0.49 \mathrm{c}$ \\
\hline $\mathrm{I}_{2}: \mathrm{GA}_{3}$ & $2.36 \mathrm{~b}$ & $2.45 b$ & $0.304 b$ & $0.309 \mathrm{~b}$ & $0.62 b$ & $0.64 b$ \\
\hline $\begin{array}{l}\mathrm{T}_{3}: \mathrm{K}_{2} \mathrm{O} \\
\mathrm{T}_{4}: \mathrm{GA}_{3}+\mathrm{K}_{2} \mathrm{O}\end{array}$ & $2.61 \mathrm{a}$ & $2.73 \mathrm{a}$ & $0.322 \mathrm{a}$ & $0.330 \mathrm{a}$ & $0.65 a$ & $0.71 \mathrm{a}$ \\
\hline F. Test & $* *$ & $*$ & $*$ & $* *$ & $* *$ & $* *$ \\
\hline CxF Interaction: & N.S & N.S & N.S & N.S & $* *$ & $* *$ \\
\hline
\end{tabular}

E.C. $=8.32$ and $8.21 \mathrm{ds} / \mathrm{m}$ in 2012 and 2013 seasons, respectively. cultivar. In addition, the lowest percentages of nitrogen cultivar. This variation in plant $\mathrm{N}, \mathrm{P}$ and proline soil conditions could mainly be due to their genetic content with Giza 178 rice cultivar could be indicator for salinity tolerance. These varietals' differences had, Bassiouni et al., (2011) and Zayed et al. (2012). contents of the three tested rice cultivars under saline also, been pointed out by several researchers, such as 
Means: followed by the same litter (s) are not significantly different, according to DMRT.

*,** and N.S.: Significant at 0.05 and 0.01 levels and not significant, respectively.

\section{Effect of $\mathrm{GA}_{3}$ and $\mathrm{K}_{2} \mathrm{O}$ applications:}

Gibberellic acid and potassium applications significantly affected plant N, P, and proline contents during both seasons of study (Table 11). The mixed treatment of $\mathrm{GA}_{3}+\mathrm{K}_{2} \mathrm{O}\left(\mathrm{T}_{4}\right)$ significantly gave the highest percentages of $\mathrm{N}, \mathrm{P}$ and proline. On the other side, the lowest contents $\mathrm{N}, \mathrm{P}$ and proline were obtained by control (without $\mathrm{GA}_{3}$ or $\mathrm{K}_{2} \mathrm{O}$ application). While, both $\mathrm{GA}_{3}$ or $\mathrm{K}_{2} \mathrm{O}$ treatments came in between. The Superiority of $\mathrm{GA}_{3}+\mathrm{K}_{2} \mathrm{O}$ treatment in increasing N, P and proline percentages could be mainly attributed to the positive effect of $\mathrm{GA}_{3}$ and $\mathrm{K}_{2} \mathrm{O}$ in enhancing nutrients absorption and translocation by rice plants(Wang et al., 2013). This trend is in harmony with those observed by Reddy et al., (2009) and Zayed (2012).

\section{Effect of the interaction:}

It is clear from data presented in Table (12) that, the highest proline content was recorded by Giza 178 rice cultivar when it treated with the mixed treatment $\left(\mathrm{GA}_{3}\right.$ $+\mathrm{K}_{2} \mathrm{O}$ ), while, the lowest percentage of proline was recorded by Giza 177 rice cultivar with the control (without $\mathrm{GA}_{3}$ and $\mathrm{K}_{2} \mathrm{O}$ application). While, the interaction between $\mathrm{GA}_{3}$ and $\mathrm{K}_{2} \mathrm{O}$ applications, as well as, rice cultivars failed to exert any significant effect on both nitrogen and phosphorus percentages in both seasons.

\section{III.Grain yield attributes:}

1. panicle length, panicle weight and 1000-grain weight.

Rice cultivars performance:

The three tested rice cultivars under saline soil conditions were significantly differed in their panicle length and weight ,as well as, 1000-grain weight (Table, 13). Giza 178 rice cultivar produced the heaviest panicles however its recorded intermediate values of panicle length and 1000-grain weight. On the other hand, Sakha 101 rice cultivar gave the heaviest 1000- grain, as well as, tallest panicles compared to the other tested two cultivars. It, also, gave intermediate values of panicle weight. In general, the lowest values of the abovementioned traits were obtained by Giza 177 rice cultivar. These results are in a parallel line with the findings of Bhowmik et al., (2007), Dong et al.,(2009), Kandil et al., (2010) and Zayed et al., (2012).

\section{Effect of $\mathrm{GA}_{3}$ and $\mathrm{K}_{2} \mathrm{O}$ applications:}

Panicle length was not significantly affected by $\mathrm{GA}_{3}$ and $\mathrm{K}_{2} \mathrm{O}$ applications. While, $\mathrm{GA}_{3}$ and $\mathrm{K}_{2} \mathrm{O}$ applications exhibited significant differences in panicle weight and 1000 -grain weight. Generally, the application of $\mathrm{GA}_{3}+$ $\mathrm{K}_{2} \mathrm{O}\left(\mathrm{T}_{4}\right)$ gave the maximum panicle weight and 1000grain weight, descending follow by $\mathrm{K}_{2} \mathrm{O}\left(\mathrm{T}_{3}\right), \mathrm{GA}_{3}\left(\mathrm{~T}_{2}\right)$ and control $\left(\mathrm{T}_{1}\right)$ treatments. Such effects of potassium and $\mathrm{GA}_{3}$ applications under saline soil conditions could be mainly attributed to improving grain filling process, especially with late $\mathrm{GA}_{3}$ and $\mathrm{K}_{2} \mathrm{O}$ applications(Hatamifar al., 2013 and Misratia et.al., 2013). The obtained data are in a good agreement with those reported by Meengoen et.al.,(2004), Gobi et al. (2006), Awan etal.(2007), Nagarathna and Prakasha (2007), Gavino et al., (2008), Geetha andVelayutham (2009), Mashmann et al,. (2010) and Wang et al., (2013) .

\section{Effect of the interaction:}

Panicle weight and 1000-grain weight were significantly affected by the interaction between $\left(\mathrm{GA}_{3}\right.$ and $\mathrm{K}_{2} \mathrm{O}$ applications) and rice cultivars as shown in Table (13). When Giza 178 rice cultivar was treated with the mixed treatment of $\mathrm{GA}_{3}+\mathrm{K}_{2} \mathrm{O}\left(\mathrm{T}_{4}\right)$ the heaviest panicle was recorded. Also, Sakha 101 rice cultivar produced the heaviest 1000-grain when it treated with $\mathrm{GA}_{3}+\mathrm{K}_{2} \mathrm{O}$ (mixed treatment). Generally, the lowest values in this respect were found by Giza 177 rice cultivar with control (without $\mathrm{GA}_{3}$ or $\mathrm{K}_{2} \mathrm{O}$ application). Tables (14 and 15).

Table 12. Effect of the interaction between $\mathrm{GA}_{3}$ and $\mathrm{K}_{2} \mathrm{O}$ applications, as well as, rice cultivars on proline percentage under saline soil conditions

\begin{tabular}{lcccccc}
\hline \multirow{2}{*}{$\mathbf{G A}_{3}$ and $\mathbf{K}_{\mathbf{2}} \mathbf{O}$ applications $(\mathbf{F})$} & \multicolumn{5}{c}{ Rice cultivars $(\mathbf{C})$} \\
\cline { 2 - 7 } & \multicolumn{5}{c}{$\mathbf{2 0 1 2}$} & \multicolumn{3}{c}{$\mathbf{2 0 1 3}$} \\
\cline { 2 - 7 } & Giza 177 & Giza 178 & Sakha 101 & Giza 177 & Giza 178 & Sakha 101 \\
\hline $\mathrm{T}_{1}:$ Control & $0.41 \mathrm{~h}$ & $0.48 \mathrm{~g}$ & $0.43 \mathrm{~h}$ & $0.42 \mathrm{j}$ & $0.50 \mathrm{~g}$ & $0.46 \mathrm{i}$ \\
$\mathrm{T}_{2}: \mathrm{GA}_{3}$ & $0.46 \mathrm{~g}$ & $0.59 \mathrm{~d}$ & $0.51 \mathrm{f}$ & $0.45 \mathrm{i}$ & $0.54 \mathrm{f}$ & $0.48 \mathrm{~h}$ \\
$\mathrm{~T}_{3}: \mathrm{K}_{2} \mathrm{O}$ & $0.53 \mathrm{ef}$ & $0.67 \mathrm{bc}$ & $0.66 \mathrm{c}$ & $0.57 \mathrm{e}$ & $0.69 \mathrm{c}$ & $0.66 \mathrm{~d}$ \\
$\mathrm{~T}_{4}: \mathrm{GA}_{3}+\mathrm{K}_{2} \mathrm{O}$ & $0.55 \mathrm{e}$ & $0.72 \mathrm{a}$ & $0.69 \mathrm{~b}$ & $0.56 \mathrm{e}$ & $0.81 \mathrm{a}$ & $0.76 \mathrm{~b}$ \\
\hline $\mathrm{E} \cdot \mathrm{C}=8.32$
\end{tabular}

E.C. $=8.32$ and $8.21 \mathrm{ds} / \mathrm{m}$ in 2012 and 2013 seasons, respectively. 
Means: followed by the same litter (s) are not significantly different, according to DMRT.

Table 13. Effect of $\mathrm{GA}_{3}$ and $\mathrm{K}_{2} \mathrm{O}$ applications on panicle length, panicle weight and 1000grain weight of three rice cultivars under saline soil conditions

\begin{tabular}{lcccccc}
\multicolumn{1}{c}{ Treatments } & \multicolumn{2}{c}{ Panicle length $(\mathbf{c m})$} & \multicolumn{2}{c}{ Panicle weight (g) } & \multicolumn{1}{c}{ 1000-grain weight (g) } \\
\cline { 2 - 7 } & $\mathbf{2 0 1 2}$ & $\mathbf{2 0 1 3}$ & $\mathbf{2 0 1 2}$ & $\mathbf{2 0 1 3}$ & $\mathbf{2 0 1 2}$ & $\mathbf{2 0 1 3}$ \\
\hline Rice cultivar $(\mathrm{C}):$ & & & & & & \\
Giza 177 & $17.45 \mathrm{c}$ & $17.29 \mathrm{c}$ & $1.64 \mathrm{c}$ & $1.75 \mathrm{c}$ & $16.32 \mathrm{c}$ & $16.68 \mathrm{c}$ \\
Giza 178 & $18.38 \mathrm{~b}$ & $18.55 \mathrm{~b}$ & $2.33 \mathrm{a}$ & $2.48 \mathrm{a}$ & $21.73 \mathrm{~b}$ & $21.22 \mathrm{~b}$ \\
Sakha 101 & $19.63 \mathrm{a}$ & $19.71 \mathrm{a}$ & $1.97 \mathrm{~b}$ & $2.04 \mathrm{~b}$ & $25.08 \mathrm{a}$ & $25.54 \mathrm{a}$ \\
\hline F. Test & $* *$ & $* *$ & $* *$ & $* *$ & $* *$ & $* *$ \\
\hline $\mathrm{GA}_{3}$ and $\mathrm{K}_{2} \mathrm{O}$ applications $(\mathrm{F}):$ & & & & & & \\
$\mathrm{T}_{1}:$ Control & 18.15 & 18.23 & $1.68 \mathrm{~d}$ & $1.76 \mathrm{~d}$ & $19.63 \mathrm{~d}$ & $19.78 \mathrm{~d}$ \\
$\mathrm{~T}_{2}: \mathrm{GA}_{3}$ & 18.37 & 18.49 & $2.06 \mathrm{~b}$ & $2.17 \mathrm{~b}$ & $20.78 \mathrm{c}$ & $21.62 \mathrm{~b}$ \\
$\mathrm{~T}_{3}: \mathrm{K}_{2} \mathrm{O}$ & 18.68 & 18.52 & $1.94 \mathrm{c}$ & $2.08 \mathrm{c}$ & $21.41 \mathrm{~b}$ & $21.12 \mathrm{c}$ \\
$\mathrm{T}_{4}: \mathrm{GA}_{3}+\mathrm{K}_{2} \mathrm{O}$ & 18.76 & 18.83 & $2.23 \mathrm{a}$ & $2.35 \mathrm{a}$ & $22.35 \mathrm{a}$ & $22.07 \mathrm{a}$ \\
\hline F. Test & N.S & N.S & $* *$ & $* *$ & $* *$ & $* *$ \\
\hline CxF Interaction: & N.S & N.S & $* *$ & $* *$ & $* *$ & $* *$ \\
\hline E. $=8.32$ a & & & & &
\end{tabular}

E.C. $=8.32$ and $8.21 \mathrm{ds} / \mathrm{m}$ in 2012 and 2013 seasons, respectively.

Means: followed by the same litter (s) are not significantly different, according to DMRT.

*,** and N.S.: Significant at 0.05 and 0.01 levels and not significant, respectively.

Table 14. Effect of the interaction between $\mathrm{GA}_{3}$ and $K_{2} \mathrm{O}$ applications, as well as, rice cultivars on panicle weight $(\mathrm{g})$ under saline soil conditions

\begin{tabular}{lcccccc}
\hline & \multicolumn{5}{c}{ Rice cultivars $(\mathbf{C})$} \\
\cline { 2 - 6 } $\mathbf{G A}_{3}$ and $\mathbf{K}_{\mathbf{2}} \mathbf{O}$ applications (F) & \multicolumn{5}{c}{$\mathbf{2 0 1 2}$} \\
\cline { 2 - 6 } & Giza 177 & Giza 178 & Sakha 101 & Giza 177 & Giza 178 & Sakha 101 \\
\hline $\mathrm{T}_{1}:$ Control & $1.32 \mathrm{i}$ & $1.94 \mathrm{de}$ & $1.78 \mathrm{~g}$ & $1.48 \mathrm{i}$ & $2.11 \mathrm{de}$ & $1.69 \mathrm{~h}$ \\
$\mathrm{~T}_{2}: \mathrm{GA}_{3}$ & $1.83 \mathrm{fg}$ & $2.46 \mathrm{~b}$ & $1.89 \mathrm{ef}$ & $2.01 \mathrm{ef}$ & $2.58 \mathrm{~b}$ & $1.93 \mathrm{fg}$ \\
$\mathrm{T}_{3}: \mathrm{K}_{2} \mathrm{O}$ & $1.57 \mathrm{~h}$ & $2.23 \mathrm{c}$ & $2.02 \mathrm{~d}$ & $1.66 \mathrm{~h}$ & $2.42 \mathrm{c}$ & $2.17 \mathrm{~d}$ \\
$\mathrm{~T}_{4}: \mathrm{GA}_{3}+\mathrm{K}_{2} \mathrm{O}$ & $1.83 \mathrm{fg}$ & $2.69 \mathrm{a}$ & $2.17 \mathrm{c}$ & $1.86 \mathrm{~g}$ & $2.81 \mathrm{a}$ & $2.38 \mathrm{c}$ \\
\hline
\end{tabular}

E.C. $=8.32$ and $8.21 \mathrm{ds} / \mathrm{m}$ in 2012 and 2013 seasons, respectively.

Means: followed by the same litter (s) are not significantly different, according to DMRT.

Table 15. Effect of the interaction between $\mathrm{GA}_{3}$ and $\mathrm{K}_{2} \mathrm{O}$ applications, as well as, rice cultivars on 1000-grain weight (g) under saline soil conditions

\begin{tabular}{lcccccc}
\hline & \multicolumn{5}{c}{ Rice cultivars $(\mathbf{C})$} \\
\cline { 2 - 7 } $\mathbf{G A}_{3}$ and $\mathbf{K}_{\mathbf{2}} \mathbf{O}$ applications $(\mathbf{F})$ & \multicolumn{3}{c}{$\mathbf{2 0 1 2}$} & \multicolumn{2}{c}{$\mathbf{2 0 1 3}$} \\
\cline { 2 - 7 } & $\mathbf{G i z a}$ & $\mathbf{G i z a}$ & \multirow{2}{*}{ Sakha 101 } & $\mathbf{G i z a}$ & $\mathbf{G i z a}$ & Sakha \\
& $\mathbf{1 7 7}$ & $\mathbf{1 7 8}$ & & $\mathbf{1 7 7}$ & $\mathbf{1 7 8}$ & $\mathbf{1 0 1}$ \\
\hline $\mathrm{T}_{1}:$ Control & $15.33 \mathrm{j}$ & $19.74 \mathrm{~g}$ & $23.81 \mathrm{~d}$ & $15.44 \mathrm{j}$ & $20.03 \mathrm{~g}$ & $23.86 \mathrm{c}$ \\
$\mathrm{T}_{2}: \mathrm{GA}_{3}$ & $16.58 \mathrm{i}$ & $21.12 \mathrm{f}$ & $24.65 \mathrm{c}$ & $16.82 \mathrm{i}$ & $21.63 \mathrm{e}$ & $26.41 \mathrm{a}$ \\
$\mathrm{T}_{3}: \mathrm{K}_{2} \mathrm{O}$ & $16.30 \mathrm{i}$ & $22.38 \mathrm{e}$ & $25.56 \mathrm{~b}$ & $17.11 \mathrm{hi}$ & $21.04 \mathrm{f}$ & $25.22 \mathrm{~b}$ \\
$\mathrm{~T}_{4}: \mathrm{GA}_{3}+\mathrm{K}_{2} \mathrm{O}$ & $17.07 \mathrm{~h}$ & $23.69 \mathrm{~d}$ & $26.28 \mathrm{a}$ & $17.35 \mathrm{~h}$ & $22.18 \mathrm{~d}$ & $26.67 \mathrm{a}$ \\
\hline
\end{tabular}

E.C. $=8.32$ and $8.21 \mathrm{ds} / \mathrm{m}$ in 2012 and 2013 seasons, respectively.

Means: followed by the same litter (s) are not significantly different, according to DMRT.

2. Number of filled grains/panicle, number of unfilled grains/panicle and sterility percentage.

Rice cultivars performance:

The three tested rice cultivars showed a wide variation in its number of filled and unfilled grains/panicle, as well as, sterility percentage (Table, 16). Giza 178 rice cultivar gave the highest number of filled grains/panicle and the lowest sterility percentage, while, the maximum number of unfilled grains/panicle and sterility percentage were obtained by Giza 177 rice cultivar in both seasons. Moreover, Sakha 101 rice cultivar came in between in this respect. These detected variation among the tested rice cultivars could mainly be attributed to their genetic background. The present findings are in agreement with those obtained by Bhowmik et al., (2007), Dong et al.,(2009), Kandil et al., (2010), Hagras et al., (2011) Abd El- 
Hamed (2013), Misratia et.al., (2013) and Shafiee et al., (2013).

Table 16. Effect of $\mathrm{GA}_{3}$ and $\mathrm{K}_{2} \mathrm{O}$ applications on number of filled grains/panicles, number of unfilled grains/panicle and sterility percentage of three rice cultivars under saline soil conditions

\begin{tabular}{|c|c|c|c|c|c|c|}
\hline \multirow[t]{2}{*}{ Treatments } & \multicolumn{2}{|c|}{$\begin{array}{l}\text { Number of filled } \\
\text { grains/panicles }\end{array}$} & \multicolumn{2}{|c|}{$\begin{array}{c}\text { Number of unfilled } \\
\text { grains/panicle }\end{array}$} & \multicolumn{2}{|c|}{$\begin{array}{c}\text { Sterility } \\
(\%) \\
\end{array}$} \\
\hline & 2012 & 2013 & 2012 & 2013 & 2012 & 2013 \\
\hline \multicolumn{7}{|l|}{ Rice cultivar $(\mathrm{C})$ : } \\
\hline Giza 177 & $93.4 \mathrm{c}$ & $92.6 \mathrm{c}$ & $30.3 \mathrm{a}$ & $29.2 \mathrm{a}$ & $24.58 \mathrm{a}$ & $24.01 \mathrm{a}$ \\
\hline Giza 178 & $114.0 \mathrm{a}$ & $112.9 \mathrm{a}$ & $16.9 \mathrm{c}$ & $17.3 \mathrm{c}$ & $13.04 \mathrm{c}$ & $13.49 \mathrm{c}$ \\
\hline Sakha 101 & $102.8 \mathrm{~b}$ & $104.5 b$ & $23.7 \mathrm{~b}$ & $22.5 b$ & $18.89 \mathrm{~b}$ & $17.86 \mathrm{~b}$ \\
\hline F. Test & $* *$ & $* *$ & $* *$ & $* *$ & $* *$ & $* *$ \\
\hline \multicolumn{7}{|c|}{$\mathrm{GA}_{3}$ and $\mathrm{K}_{2} \mathrm{O}$ applications $(\mathrm{F})$ : } \\
\hline $\mathrm{T}_{1}:$ Control & $91.2 \mathrm{~d}$ & $89.4 \mathrm{c}$ & $29.4 \mathrm{a}$ & $27.5 \mathrm{a}$ & $24.24 \mathrm{a}$ & $23.65 \mathrm{a}$ \\
\hline $\mathrm{T}_{2}: \mathrm{GA}_{3}$ & $107.8 \mathrm{~b}$ & $105.9 b$ & $22.6 \mathrm{c}$ & $21.8 \mathrm{c}$ & $17.45 \mathrm{c}$ & $17.12 \mathrm{c}$ \\
\hline $\mathrm{T}_{3}: \mathrm{K}_{2} \mathrm{O}$ & $103.1 \mathrm{c}$ & $104.8 b$ & $24.1 b$ & $24.7 b$ & $19.02 b$ & $19.19 b$ \\
\hline $\mathrm{T}_{4}: \mathrm{GA}_{3}+\mathrm{K}_{2} \mathrm{O}$ & $111.5 \mathrm{a}$ & $113.2 \mathrm{a}$ & $18.5 \mathrm{~d}$ & $18.0 \mathrm{~d}$ & $14.38 \mathrm{~d}$ & $13.84 d$ \\
\hline F. Test & $* *$ & $* *$ & $* *$ & $* *$ & $* *$ & $* *$ \\
\hline CxF Interaction: & $* *$ & $* *$ & $* *$ & $* *$ & $* *$ & $* *$ \\
\hline
\end{tabular}

E.C. $=8.32$ and $8.21 \mathrm{ds} / \mathrm{m}$ in 2012 and 2013 seasons, respectively.

Means: followed by the same litter (s) are not significantly different, according to DMRT.

*,** and N.S.: Significant at 0.05 and 0.01 levels and not significant, respectively.

\section{Effect of $\mathrm{GA}_{3}$ and $\mathrm{K}_{2} \mathrm{O}$ applications:}

$\mathrm{GA}_{3}$ and $\mathrm{K}_{2} \mathrm{O}$ applications used in this study exhibited significant differences in panicle weight, number of filled and unfilled grains/panicle, as well as, sterility percentage., The application of $\mathrm{GA}_{3}+\mathrm{K}_{2} \mathrm{O}$ gave the maximum number of filled grains/panicle, as well as, the lowest number of unfilled grains/panicle and sterility percentage (Table,16). On contrast, the lowest number of filled grains/panicle, as well as, the highest number of unfilled grains/panicle and sterility percentage where recorded with control(without $\mathrm{GA}_{3}$ or $\mathrm{K}_{2} \mathrm{O}$ application). Such effects of potassium and $\mathrm{GA}_{3}$ applications in improving rice grain filling under saline soil conditions could be mainly attributed to encourage faster and earlier growth and improve the photosynthesis rate, which consequently increase stored carbohydrates at pre-heading which relatively translocated to the panicles, consequently increased filling of spikelets (Gobi et al., 2008 and Pan et al., 2013). The obtained data are in a good agreement with those reported by Meengoen et.al.,(2004), Gobi et al., (2006), Awan etal.(2007), Nagarathna and Prakasha (2007), Gavino et al., (2008), Geetha andVelayutham (2009), Mashmann et al., (2010) and Hatamifar al., (2013).

\section{Effect of the interaction:}

With respect to the interaction between rice cultivars, as well as, $\mathrm{GA}_{3}$ and $\mathrm{K}_{2} \mathrm{O}$ applications, Tables
(17, 18 and 19) indicated that, Giza 178 rice cultivar gave the highest number of filled grains/panicle , as well as, the lowest number of unfilled grains/panicle and sterility percentage in both 2012 and 2013 seasons when it treated with $\mathrm{GA}_{3}+\mathrm{K}_{2} \mathrm{O}\left(\mathrm{T}_{4}\right)$, while, Giza 177 rice cultivar with the control $\left(\mathrm{T}_{1}\right)$ gave the highest number of unfilled grains/panicle and sterility percentage, as well as, the lowest number of filled grains/panicle.

\section{Grain yield, straw yield and harvest index.}

Rice cultivars performance:

It could be easily observed from data presented in Table (20) that, the three tested rice cultivars were statistically varied in their grain and straw yields, as well as, harvest index. Giza 178 rice cultivar produced the maximum grain yield and harvest index during both seasons of investigation. The lowest harvest index was obtained by Giza 177 rice cultivar as a result to produce the lowest grain and straw yields. On the other side, the maximum straw yield was belonged with Sakha 101 rice cultivar. Such variation probably due to the differences among the tested rice cultivars in their vegetative growth behavior and genetic variability. The superiority of Giza 178 rice cultivar in grain yield could be mainly attributed to it recorded the maximum values of panicle weight and number of filled grains/panicle, as well as, the lowest number of unfilled grains/panicle and sterility percentage. In addition Giza 178 rice 
cultivar could be considered salt-tolerant cultivar (Zayed et al., 2007).

The obtained results are in accordance with the findings of Bhowmik et al., (2007),Bassiouni (2011), Okasha,Amira(2011),Zayed et al., (2012) and Abd ElHamed (2013).

\section{Effect of $\mathrm{GA}_{3}$ and $\mathrm{K}_{2} \mathrm{O}$ applications:}

It was clear from Table (20) that, during both seasons of investigation potassium and gibberellic acid treatments significantly affected grain yield, straw yield and harvest index. The application of $\mathrm{GA}_{3}+\mathrm{K}_{2} \mathrm{O}\left(\mathrm{T}_{4}\right)$ recorded the maximum grain and straw yields ,as well as, harvest index. On the other side, the lowest grain and straw yields were recorded with the control $\left(\mathrm{T}_{1}\right)$. Growth regulator treatment $\left(\mathrm{T}_{2}\right)$ which was statistically at par with the nutrient treatment $\left(\mathrm{T}_{3}\right)$ recorded intermediate values. Furthermore, such effect of potassium and gibberellic acid application in improving rice productivity under salinity conditions were caused by increased grain yield attributes; i.e, , panicle length and weight, 1000-grain weight and number of filled grains/panicle. Data in Tables (13 and 16) supported these findings. Superiority of $\left(\mathrm{T}_{4}\right)$ treatment might be due to partitioning potassium and gibberellic acid through several integrated soil and foliar application doses during vegetative period, which increase dry matter contents, consequently promote growth patterns and delay plant senescence, as well as, improve the photosynthesis rate and which increase stored carbohydrates at pre-heading which relatively translocated to the panicles, consequently increased filling of spikelets (Gobi et al., 2008 and Pan et al., 2013). Such results are in line with those recorded by Gavino et al., (2008), Geetha and Velayutham (2009), Mashmann et al. (2010), Bassiouni (2011), Zayed et al., (2012), Abd El-Hamed (2013), Shafiee et al., (2011). and Wang al., (2013).

Effect of the interaction:

Table (20) reveals that, grain and straw yields of all tested rice cultivars were significantly affected by the interaction between rice cultivars, as well as, $\mathrm{GA}_{3}$ and $\mathrm{K}_{2} \mathrm{O}$ applications during two investigation seasons. Interestingly, Giza 178 rice cultivar with $\mathrm{GA}_{3}+\mathrm{K}_{2} \mathrm{O}$ $\left(\mathrm{T}_{4}\right)$ produced the maximum grain yield and harvest index, while, the maximum straw yield was obtained by Sakha 101 rice cultivar with $\mathrm{GA}_{3}+\mathrm{K}_{2} \mathrm{O}\left(\mathrm{T}_{4}\right)$.

On contrary, the minimum grain and straw yields, as well as, harvest index were recorded by Giza 177 rice cultivar with the control $\left(\mathrm{T}_{1}\right)$ (Tables, 21,22 and 23).

This study concluded that, rice growers were advised to soak rice paddy grains in gibberellic acid solution at the concentration of $100 \mathrm{ppm}$, adding $45 \mathrm{~kg} \mathrm{~K} 2 \mathrm{O} / \mathrm{ha}$. as basal application and spry rice plants with $10 \mathrm{mg} / \mathrm{l}$ and $2 \%$ of gibberellic acid and, $\mathrm{K}_{2} \mathrm{O}$ solution, respectively, two times at mid of tillering and panicle initiation growth stages to mitigate salinity harmful, improve growth and enhance grain yield.

Table 17. Effect of the interaction between $\mathrm{GA}_{3}$ and $\mathrm{K}_{2} \mathrm{O}$ applications, as well as, rice cultivars on number of filled grains/panicle under saline soil conditions

\begin{tabular}{lcccccc}
\hline \multirow{2}{*}{$\mathbf{G A}_{3}$ and $K_{2} \mathbf{O}$ applications $(\mathbf{F})$} & \multicolumn{5}{c}{ Rice cultivars $(\mathbf{C})$} \\
\cline { 2 - 6 } & \multicolumn{3}{c}{$\mathbf{2 0 1 2}$} \\
\cline { 2 - 6 } & Giza 177 & Giza 178 & Sakha 101 & Giza 177 & Giza 178 & Sakha 101 \\
\hline $\mathrm{T}_{1}:$ Control & $81.6 \mathrm{k}$ & $100.2 \mathrm{~g}$ & $91.7 \mathrm{j}$ & $77.1 \mathrm{~h}$ & $98.4 \mathrm{e}$ & $92.6 \mathrm{~g}$ \\
$\mathrm{~T}_{2}: \mathrm{GA}_{3}$ & $97.3 \mathrm{~h}$ & $119.8 \mathrm{~b}$ & $106.4 \mathrm{e}$ & $96.2 \mathrm{f}$ & $116.5 \mathrm{~b}$ & $104.9 \mathrm{c}$ \\
$\mathrm{T}_{3}: \mathrm{K}_{2} \mathrm{O}$ & $93.1 \mathrm{i}$ & $113.6 \mathrm{c}$ & $102.5 \mathrm{f}$ & $94.5 \mathrm{fg}$ & $115.7 \mathrm{~b}$ & $104.2 \mathrm{~cd}$ \\
$\mathrm{~T}_{4}: \mathrm{GA}_{3}+\mathrm{K}_{2} \mathrm{O}$ & $101.4 \mathrm{fg}$ & $122.3 \mathrm{a}$ & $110.7 \mathrm{~d}$ & $102.6 \mathrm{~d}$ & $120.8 \mathrm{a}$ & $116.3 \mathrm{~b}$ \\
\hline
\end{tabular}

E.C. $=8.32$ and $8.21 \mathrm{ds} / \mathrm{m}$ in 2012 and 2013 seasons, respectively.

Means: followed by the same litter (s) are not significantly different, according to DMRT.

Table 18. Effect of the interaction between $\mathrm{GA}_{3}$ and $\mathrm{K}_{2} \mathrm{O}$ applications, as well as, rice cultivars on number of unfilled grains/panicle under saline soil conditions

\begin{tabular}{lccccccc}
\hline \multirow{2}{*}{ GA $_{3}$ and $\mathbf{K}_{\mathbf{2}} \mathbf{O}$ applications $(\mathbf{F})$} & \multicolumn{6}{c}{ Rice cultivars (C) } \\
\cline { 2 - 7 } & \multicolumn{7}{c}{$\mathbf{2 0 1 2}$} \\
\cline { 2 - 7 } & Giza 177 & Giza 178 & Sakha 101 & Giza 177 & Giza 178 & Sakha 101 \\
\hline $\mathrm{T}_{1}:$ Control & $36.7 \mathrm{a}$ & $22.8 \mathrm{f}$ & $28.6 \mathrm{c}$ & $32.7 \mathrm{a}$ & $23.5 \mathrm{f}$ & $26.3 \mathrm{~cd}$ \\
$\mathrm{~T}_{2}: \mathrm{GA}_{3}$ & $28.9 \mathrm{c}$ & $17.0 \mathrm{i}$ & $21.9 \mathrm{~g}$ & $27.3 \mathrm{c}$ & $17.0 \mathrm{~h}$ & $21.2 \mathrm{~g}$ \\
$\mathrm{~T}_{3}: \mathrm{K}_{2} \mathrm{O}$ & $31.4 \mathrm{~b}$ & $15.6 \mathrm{j}$ & $25.3 \mathrm{~d}$ & $31.4 \mathrm{~b}$ & $18.2 \mathrm{~h}$ & $24.5 \mathrm{ef}$ \\
$\mathrm{T}_{4}: \mathrm{GA}_{3}+\mathrm{K}_{2} \mathrm{O}$ & $24.2 \mathrm{e}$ & $12.3 \mathrm{k}$ & $19.0 \mathrm{~h}$ & $25.3 \mathrm{de}$ & $10.6 \mathrm{i}$ & $18.1 \mathrm{~h}$ \\
\hline
\end{tabular}

E.C. $=8.32$ and $8.21 \mathrm{ds} / \mathrm{m}$ in 2012 and 2013 , respectively. 
Means: followed by the same litter (s) are not significantly different, according to DMRT.

Table 19. Effect of the interaction between $\mathrm{GA}_{3}$ and $\mathrm{K}_{2} \mathrm{O}$ applications, as well as, rice cultivars number of sterility (\%) under saline soil conditions

\begin{tabular}{lcccccc}
\hline \multirow{2}{*}{$\mathbf{G A}_{3}$ and $\mathbf{K}_{\mathbf{2}} \mathbf{O}$ applications $(\mathbf{F})$} & \multicolumn{5}{c}{ Rice cultivars $(\mathbf{C})$} \\
\cline { 2 - 7 } & \multicolumn{3}{c}{$\mathbf{2 0 1 2}$} & \multicolumn{3}{c}{$\mathbf{2 0 1 3}$} \\
\cline { 2 - 7 } & Giza 177 & Giza 178 & Sakha 101 & Giza 177 & Giza 178 & Sakha 101 \\
\hline $\mathrm{T}_{1}:$ Control & $30.98 \mathrm{a}$ & $18.53 \mathrm{f}$ & $23.97 \mathrm{c}$ & $29.56 \mathrm{a}$ & $19.28 \mathrm{~d}$ & $22.12 \mathrm{c}$ \\
$\mathrm{T}_{2}: \mathrm{GA}_{3}$ & $22.89 \mathrm{~d}$ & $12.42 \mathrm{i}$ & $17.05 \mathrm{~g}$ & $21.82 \mathrm{c}$ & $12.73 \mathrm{f}$ & $16.81 \mathrm{e}$ \\
$\mathrm{T}_{3}: \mathrm{K}_{2} \mathrm{O}$ & $25.21 \mathrm{~b}$ & $12.06 \mathrm{i}$ & $19.79 \mathrm{e}$ & $24.93 \mathrm{~b}$ & $13.59 \mathrm{f}$ & $19.04 \mathrm{~d}$ \\
$\mathrm{~T}_{4}: \mathrm{GA}_{3}+\mathrm{K}_{2} \mathrm{O}$ & $19.25 \mathrm{e}$ & $9.13 \mathrm{j}$ & $14.76 \mathrm{~h}$ & $19.73 \mathrm{~d}$ & $8.34 \mathrm{~g}$ & $13.46 \mathrm{f}$ \\
\hline
\end{tabular}

E.C. $=8.32$ and $8.21 \mathrm{ds} / \mathrm{m}$ in 2012 and 2013 seasons, respectively.

Means: followed by the same litter ( $\mathrm{s}$ ) are not significantly different, according to DMRT.

Table20. Effect of $\mathrm{GA}_{3}$ and $\mathrm{K}_{2} \mathrm{O}$ applications on grain yield, straw yield and harvest index of three rice cultivars under saline soil conditions

\begin{tabular}{|c|c|c|c|c|c|c|}
\hline \multirow{2}{*}{ Treatments } & \multicolumn{2}{|c|}{ Grain yield (t/ha.) } & \multicolumn{2}{|c|}{ Straw yield (t/ha.) } & \multicolumn{2}{|c|}{ Harvest index (HI) } \\
\hline & 2012 & 2013 & 2012 & 2013 & 2012 & 2013 \\
\hline Rice cultivar (C): & $4.98 \mathrm{c}$ & $5.03 \mathrm{c}$ & $7.93 \mathrm{c}$ & $7.88 \mathrm{c}$ & $38.55 \mathrm{c}$ & $38.92 \mathrm{c}$ \\
\hline $\begin{array}{l}\text { Giza } 177 \\
\text { Giza } 178\end{array}$ & $6.45 \mathrm{a}$ & $6.38 \mathrm{a}$ & $8.68 b$ & $8.37 b$ & $42.43 \mathrm{a}$ & $43.06 \mathrm{a}$ \\
\hline $\begin{array}{l}\text { Giza } 178 \\
\text { Sakha } 101\end{array}$ & $6.05 b$ & $5.94 b$ & $9.16 \mathrm{a}$ & $8.83 \mathrm{a}$ & $39.72 b$ & $39.84 b$ \\
\hline F. Test & $* *$ & $* *$ & $* *$ & $* *$ & $* *$ & $* *$ \\
\hline \multicolumn{7}{|c|}{$\mathrm{GA}_{3}$ and $\mathrm{K}_{2} \mathrm{O}$ applications $(\mathrm{F})$ : } \\
\hline $\mathrm{T}_{1}:$ Control & $5.17 \mathrm{~d}$ & $5.29 \mathrm{~d}$ & $7.68 \mathrm{c}$ & $7.59 \mathrm{~d}$ & $40.16 b$ & $40.91 b$ \\
\hline $\mathrm{T}_{2}: \mathrm{GA}_{3}$ & $5.91 b$ & $5.72 b$ & $8.85 b$ & $8.53 b$ & $39.70 \mathrm{c}$ & $39.76 \mathrm{c}$ \\
\hline $\mathrm{T}_{3}: \mathrm{K}_{2} \mathrm{O}$ & $5.69 \mathrm{c}$ & $5.48 \mathrm{c}$ & $8.69 b$ & $8.27 \mathrm{c}$ & $39.42 \mathrm{c}$ & $39.32 \mathrm{c}$ \\
\hline $\mathrm{T}_{4}: \mathrm{GA}_{3}+\mathrm{K}_{2} \mathrm{O}$ & $6.53 a$ & $6.64 \mathrm{a}$ & $9.13 \mathrm{a}$ & $9.04 \mathrm{a}$ & $41.64 \mathrm{a}$ & $42.43 \mathrm{a}$ \\
\hline F. Test & $* *$ & $* *$ & $* *$ & $* *$ & $* *$ & $* *$ \\
\hline CxF Interaction: & $* *$ & $* *$ & $* *$ & $* *$ & $* *$ & $*$ \\
\hline
\end{tabular}

E.C. $=8.32$ and $8.21 \mathrm{ds} / \mathrm{m}$ in 2012 and 2013 seasons, respectively.

Means: followed by the same litter (s) are not significantly different, according to DMRT.

*,** and N.S.: Significant at 0.05 and 0.01 levels and not significant, respectively.

Table 21. Effect of the interaction between $\mathrm{GA}_{3}$ and $\mathrm{K}_{2} \mathrm{O}$ applications, as well as, rice cultivars on grain yield ( $t / h a$.) under saline soil conditions.

\begin{tabular}{ccccccc}
\hline \multirow{2}{*}{$\mathbf{G A}_{3}$ and $\mathbf{K}_{\mathbf{2}} \mathbf{O}$ applications $(\mathbf{F})$} & \multicolumn{5}{c}{ Rice cultivars $(\mathbf{C})$} \\
\cline { 2 - 7 } & \multicolumn{5}{c}{$\mathbf{2 0 1 2}$} & \multicolumn{3}{c}{$\mathbf{2 0 1 3}$} \\
\cline { 2 - 7 } & Giza 177 & Giza 178 & Sakha 101 & Giza 177 & Giza 178 & Sakha 101 \\
\hline $\mathrm{T}_{1}:$ Control & $4.56 \mathrm{k}$ & $5.63 \mathrm{~g}$ & $5.32 \mathrm{~h}$ & $4.71 \mathrm{j}$ & $5.76 \mathrm{f}$ & $5.40 \mathrm{~h}$ \\
$\mathrm{~T}_{2}: \mathrm{GA}_{3}$ & $4.92 \mathrm{i}$ & $6.58 \mathrm{c}$ & $6.23 \mathrm{e}$ & $5.05 \mathrm{i}$ & $6.13 \mathrm{~d}$ & $5.97 \mathrm{e}$ \\
$\mathrm{T}_{3}: \mathrm{K}_{2} \mathrm{O}$ & $4.76 \mathrm{j}$ & $6.47 \mathrm{~d}$ & $5.84 \mathrm{f}$ & $4.62 \mathrm{j}$ & $6.28 \mathrm{c}$ & $5.54 \mathrm{~g}$ \\
$\mathrm{~T}_{4}: \mathrm{GA}_{3}+\mathrm{K}_{2} \mathrm{O}$ & $5.68 \mathrm{~g}$ & $7.12 \mathrm{a}$ & $6.79 \mathrm{~b}$ & $5.73 \mathrm{f}$ & $7.35 \mathrm{a}$ & $6.84 \mathrm{~b}$ \\
\hline $\mathrm{E}$
\end{tabular}

E.C. $=8.32$ and $8.21 \mathrm{ds} / \mathrm{m}$ in 2012 and 2013 seasons, respectively.

Means: followed by the same litter (s) are not significantly different, according to DMRT.

Table 22. Effect of the interaction between $\mathrm{GA}_{3}$ and $\mathrm{K}_{2} \mathrm{O}$ applications, as well as, rice cultivars on straw yield ( $t / \mathbf{h a}$.) under saline soil conditions.

$\mathrm{GA}_{3}$ and $\mathrm{K}_{2} \mathrm{O}$ applications (F)

\begin{tabular}{lccccc}
\hline \multicolumn{5}{c}{ Rice cultivars (C) } \\
\hline Giza 177 & Giza 178 & Sakha 101 & Giza 177 & Giza 178 & Sakha 101 \\
\hline
\end{tabular}




\begin{tabular}{lcccccc}
\hline $\mathrm{T}_{1}:$ Control & $7.07 \mathrm{~h}$ & $7.48 \mathrm{~g}$ & $8.49 \mathrm{de}$ & $7.19 \mathrm{e}$ & $7.43 \mathrm{e}$ & $8.14 \mathrm{~d}$ \\
$\mathrm{~T}_{2}: \mathrm{GA}_{3}$ & $8.04 \mathrm{f}$ & $9.18 \mathrm{bc}$ & $9.33 \mathrm{bc}$ & $8.23 \mathrm{~d}$ & $8.67 \mathrm{c}$ & $8.69 \mathrm{c}$ \\
$\mathrm{T}_{3}: \mathrm{K}_{2} \mathrm{O}$ & $8.39 \mathrm{de}$ & $8.65 \mathrm{~d}$ & $9.04 \mathrm{c}$ & $7.94 \mathrm{~d}$ & $8.09 \mathrm{~d}$ & $8.78 \mathrm{c}$ \\
$\mathrm{T}_{4}: \mathrm{GA}_{3}+\mathrm{K}_{2} \mathrm{O}$ & $8.23 \mathrm{ef}$ & $9.41 \mathrm{~b}$ & $9.76 \mathrm{a}$ & $8.15 \mathrm{~d}$ & $9.28 \mathrm{~b}$ & $9.71 \mathrm{a}$ \\
\hline
\end{tabular}

E.C. $=8.32$ and $8.21 \mathrm{ds} / \mathrm{m}$ in 2012 and 2013 seasons, respectively.

Means: followed by the same litter (s) are not significantly different, according to DMRT.

Table 23. Effect of the interaction between $\mathrm{GA}_{3}$ and $\mathrm{K}_{2} \mathrm{O}$ applications, as well as, rice cultivars on harvest index under saline soil conditions

\begin{tabular}{ccccccc}
\hline \multirow{2}{*}{$\mathbf{G A}_{\mathbf{3}}$ and $\mathbf{K}_{\mathbf{2}} \mathbf{O}$ applications $(\mathbf{F})$} & \multicolumn{7}{c}{ Rice cultivars (C) } \\
\cline { 2 - 7 } & \multicolumn{7}{c}{$\mathbf{2 0 1 2}$} & \multicolumn{3}{c}{$\mathbf{2 0 1 3}$} \\
\cline { 2 - 7 } & Giza 177 & Giza 178 & Sakha 101 & Giza 177 & Giza 178 & Sakha 101 \\
\hline $\mathrm{T}_{1}:$ Control & $39.20 \mathrm{a}$ & $42.75 \mathrm{a}$ & $38.54 \mathrm{de}$ & $39.58 \mathrm{~d}$ & $43.67 \mathrm{ab}$ & $39.49 \mathrm{~d}$ \\
$\mathrm{~T}_{2}: \mathrm{GA}_{3}$ & $37.95 \mathrm{e}$ & $41.11 \mathrm{~b}$ & $40.04 \mathrm{c}$ & $38.03 \mathrm{ef}$ & $41.41 \mathrm{c}$ & $39.84 \mathrm{~d}$ \\
$\mathrm{~T}_{3}: \mathrm{K}_{2} \mathrm{O}$ & $36.21 \mathrm{i}$ & $42.79 \mathrm{a}$ & $39.26 \mathrm{~cd}$ & $36.78 \mathrm{f}$ & $42.50 \mathrm{bc}$ & $38.68 \mathrm{de}$ \\
$\mathrm{T}_{4}: \mathrm{GA}_{3}+\mathrm{K}_{2} \mathrm{O}$ & $4.83 \mathrm{~b}$ & $43.08 \mathrm{a}$ & $41.02 \mathrm{~b}$ & $41.29 \mathrm{c}$ & $44.66 \mathrm{a}$ & $41.35 \mathrm{c}$ \\
\hline
\end{tabular}

E.C. $=8.32$ and $8.21 \mathrm{ds} / \mathrm{m}$ in 2012 and 2013 seasons, respectively.

Means: followed by the same litter (s) are not significantly different, according to DMRT.

\section{REFERENCES}

A.O.A.C. (1970). "Association of Official Agriculture Chemists" Official Methods of Analysis. $10^{\text {th }}$ ed. Washington, D.C., U.S.A.

Abd El-Hamed M. (2013). Effect of Rates and time of potassium fertilizer application on yield of hybrid rice. Ph.D. Thesis, Agron. Dept., Fac. of Agric., Al-Azhar Univ., Egypt.

Awan T., Z. Manzoor, E. Safdar and M. Ahmed. (2007). Yield response of rice to dynamic use of potassium in traditional rice growing area of Punjab. Pak. J. Agric. Sci., 44(1): 130-134.

Baskar M.,A. Solaiman, C . Sivakumar and R . Suresh . (2000). Phosphourus management in rice . Indian J. Agric. Rev.,21(3):168-177.

Bassiouni S. (2011). Response of some rice cultivars to diammonium phosphate and gibberellic acid application under saline soil conditions. Ph.D. Thesis, Agron. Dept., Fac. of Agric., Kafrelsheikh Univ., Egypt.

Bassiouni S., B. Zayed; A. Mohamed and A. Omer. (2011). Effect of pre-sowing seed and seedling treatments on growth and yield of Egyptian hybrid rice under saline soil conditions. J. Agric. Res., Kafr El-Sheikh Univ., 37(2): 270-283.

Bates L., R. Walldrn and Taere. (1973). Rapid determention of free proline for water stress studies. Plant and Soil, 79: 205-210.

Bhowmik S., M. Islam, R. Emon, Begum S.; A. Siddika and S. Sultana. (2007). Identification of salt tolerant rice cultivars via phenotypic and Marker-Assisted Procedures. Pak. J. of Biol. Sci., 10(24): 4449-4454.

Black C. (1983). Methods of soil analysis, Part I and II. Amer. Agron. Inc. Publ., Madison, Wisconsin, U.S.A.

Chen D., T. Gunawardena, B. Naidu, S. Fukai and J. Basnayake. (2005). Seed treatment with gibberellic acid and glycinebetaine improves seedling emergence and seedling vigor of rice under low temperature. Seed sci. and tech., 33(2):471-479.

Dong M. L. Bin; L. Quan, Z. Hong and Y. Chang. (2009). Effects of exogenous ABA and GA on the main quality characteristics of grains at different positions of panicle in rice. Acta Agronomica Sinica, 35(5): 899-906.

Duncan B. (1955). Multiple Range and Multiple F. Test. Biometrics., 11: 1-42.

El-Mowafi H. (1994). Studies on rice breeding. Ph.D. Thesis, Agron. Dept., Fac. of Agric., Kafr El-Sheikh, Tanta Univ., Egypt.

Farooq M., S. Basra, A. Wahid, Z. Cheema, M. Cheema, and A. Khaliq. (2008). Physiological role exogenously applied glycinebetaineto improve drought tolerance in fine grain aromatic rice (Oryza sativa L.). J. of Agron. and Crop Sci., 194(5): 325-333.

Fu Z. T. Bai and Q. Xu. (2009). Proteomics reveals the effects of Gibberelic acid $\left(\mathrm{GA}_{3}\right)$ on salt-stressed rice (Oryza sativa, L.) shoots. J. Plant Sci., 11:6.

Gavino B., Y. Pi and C. Abon. (2008). Application of gibberellic acid $\left(\mathrm{GA}_{3}\right)$ in dosages for three hybrid rice seed production in the Philippines. J. of Agric. Tech., 4(1): 183-192.

Geetha P. and A. Velayutham. (2009). Refinement of nutrient management techniques for growth, yield and nutrient uptake of rice fallow blackgram. Madras Agric. J., 96: (16): 163-166.

Gobi R., J. Pandian and S. Kanaka. (2006). Evaluation of stand establishment methods and split application of $\mathrm{N}$ and $\mathrm{K}$ for hybrid rice (CORH 2). Crop Res. Hisar, 23(3): 275-278.

Gobi R., S. Ramesh, J. Pandian and B. Handrasekaran. (2008). Evaluation of establishment methods and split application of $\mathrm{N}$ and $\mathrm{K}$ on growth analysis, NPK uptake, nitrogen use efficiency and soil fertility status of CORH2 rice hybrid. International J. of Agric. Sci., 4(1): 173-180. 
Gomez K. and A. Gomez. (1984). Statistical procedures of Agricultural Research. John Wiley and Sons. Inc., New York, U.S.A.

Hagrras A., B. Zayed, N. Doula and A. Zayed. (2011). Effect of nitrogen and potassium levels on yield and yield components of rice genotypes under saline soils. J. Pl. production, Mansoura Univ., 2(12):1907-1917.

Hatamifar B., M. Ashoury, H. Vahed . and P. Shahin. (2013). Effects of Irrigation and Various Rates of Nitrogen and Potassium on Yield and Yield Components of Rice Plant (Oryza sativa L.). Rokhsar Persian Gulf Crop Protection, 2(2): 19-25.

Hong H. and G. Wang. (2004). Nutrient uptake and use efficiency of irrigated rice in response to potassium application. Redoshere J., 14(1): 125-130.

IRRI-Standard Evaluation System of Rice. (1996). Standard Evaluation System for Rice. $3^{\text {rd }}$ ed. Int. Rice. Res. Inst., Loss Banos, Philippines.

Jackson N. (1967). Soil chemical analysis. Prentice-Hall Inc. Englewood Cliff. S.N.S.

Kandil A., M. Sultan, M. Badawi, A. Abd El-Rahman and B. Zayed. (2010). Performance of some rice cultivars as affected by irrigation and potassium fertilizer under saline soil conditions: I-yield and yield components. Crop and Environ., 1(1): 18-21.

Khan M. and Z. Abdallah. (2003). Salinity-sodicitiy induced changes in reproductive physiology of rice (Oryza sativa) under dense soil conditions. Environ. and Experim. Bot., 49(2): 145-157.

Krishnakumar S., R. Nagarajan, S. Natarajan, D. Jawahar and B. Pandian. (2005). NPK fertilizers for hybrid rice (Oryza sativa L.) productivity in Alfisols of Southern Districts of Tamil Nadu. Asian J. of Plant Sci., 4(6): 574-576.

Manzoor Z., T. Awan, M. Ahmed, M. Akhter and F. Faiz. (2008). Effect of split application of potash on yield and yield related traits of basmati rice. J. Anim. Pl. Sci., 18(4): 120-124.

Mashmann E., N. Slaton, R. Corwright and J. Norman. (2010). Rate and timing of potassium fertilization and fungicide influence rice yield and stem rot. Agron. J., 102(2): 163170.

Meena S., S. Singh and Y. Shivay. (2003). In Response of hybrid rice (Oryza. Sativa L.) to nitrogen and potassium application in sandy clay loam soils. Indian J. of Agricultural Sci., 73(1): 8-11.

Meengoen K., N. Jungtawong, W. Arirob and K. Distabanjog. (2004). Effect of plant growth regulators on changes of amylase, protein and beta-carotene in rice grains. Proceeding of the $24^{\text {nd }}$ Kasetsart University Annual Conference, Kasetstart, Thailand, 3-6 February, 2004, pp. 33-39.

Misratia K., M. Ismail, F. Oad, M. Hanafi and A. Puteh. (2013). Effect of Salinity and Alleviating Role of Gibberellic Acid (GA3) for Enhancement of Rice Yield. Inter. J. of Chem., Environ. \& Biol. Sci. (IJCEBS).1(2): 2320-4087.
Nagarathna T. and H. Prakasha. (2007). Synchronization of potassium supply in rice hybrids. Environ. and Ecol., 25(3-4): 967-968.

Okasha, Amira M. (2011). Rice fertilizer under saline soil condition. Ph. D. Thesis, Agron. Dept., Fac. of Agric., Zagazig Univ., Egypt.

Pan S., F. Rasul, W. Li, H. Tian, Z. Mo, M. Duan and Xiangru Tang. (2013). Roles of plant growth regulators on yield, grain qualities and antioxidant enzyme activities in super hybrid rice. A Spring open J., http://www.thericejournal.com/content/6/1/9.

Pandey N., K. Verma, A. Anurag and S. Tripathi .(2007). Integrated nutrient management in transplanted hybrid rice (Oryza sativa L.) Indian J. of Agron., 52(1): 49-51.

Piper C. (1950). Soil and plant analysis. Inc. Soc., Publ. Inc., New York, U.S.A.

Reddy N., K. Keshhavulu, K. Durga, R. Ankaiah and A. Kumar. (2009). Effect of nutrients alternate to $\mathrm{GA}_{3}$ on yield and quality in hybrid rice seed production. Res. on Crop, 10(3): 718-727.

Sairam R., and A. Tyagi. (2004).Physiology and molecular biology of salinity stress tolerance in plants. Curr. Sci.,86:407-721.

Shafiee M., A. Boyce, M. Khandaker, J. Saad, .Aziz, M. Mispan, M. Anuar and B. Hj Bakar. (2013). Pilot Studies on Rice Yield Enhancement with Foliar Application of SBAJA in Sungai Besar, Selangor, Malaysia. Life Sci. J.,10(1): 329-335.

Sing R. and S. Singh. (1998). Response of rice (Oriza sativa L.) to age of seedlings and level and time of application of nitrogen under irrigated conditions. Indian J. of Agron., 43(4): 632-635.

Sivakumar S., B. Gururajan, K. Thirukumaran, C. Babu, R. Umashankar and P. Sureshkumar. (2007). Maximizing the Rabi rice producitivity through nutrient foliar spray. J. of Ecobiology, 20(1): 9-15.

Sucharitha R. and S. Boopathi. (2000). Growth and yield of rice varieties as influenced by phosphorus application to nursery and main field. J. Res. Agric., 29(40: 9-15.

Sumontip B. and P. Pongthai. (2013). Selection of Rice (Oryza sativa L.) Cultivars Tolerant to Drought Stress at the Vegetative Stage under Field Conditions. Amer. J. of Pl. Sci., 4: 1701-1708.

Sundari A. and S. Sureshkumar. (2004). Influence of DAP and phosphobacteria on growth and yield blackgram under rice-fallow condition. Indian J. of Ecobiology , 16(1):7577.

Wang M., Q. Zheng, Q. Shen and S. Guo. (2013). The Critical Role of Potassium in Plant Stress Response. Int. J. Mol. Sci., 14:7370-7390.

Zayed B. (2012). The role of phosphorous management in Salinity tolerance alleviation in rice crop. Egypt Agric. Res., 90(2): 667-685.

Zayed B., A. El-Gouhary, A. El-Ekhtyar and S. Sedeek. (2006). Response of Giza 177 and SK2034H hybrid rice to 
potassium splitting. $1^{\text {st }}$ Field Crops Conf., August 22-24, Giza, Egypt, pp: 407-414.

Zayed B., R. El-Namaky, I. El-Refaee and S. Seddek. (2012). Comparative study on hybrid and inbred rice under drought and saline stresses. J. Plant Production, Mansoura Univ., 3(1): 91-108.
Zayed B., W. El-Khoby, S. Shehata and H. Amar. (2007). Role of potassium application on productivity of some inbred and hybrid rice varities under newly reclaimed saline soils. African Crop Sci. Con. Proceeding., 8: 53-60.

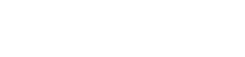

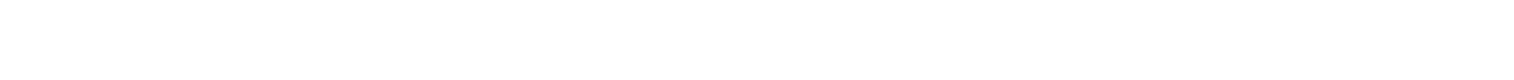

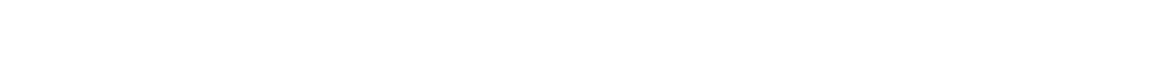

مرحلة بدأ نشوء الداليه)، (ع): المعلملة بكل من البوتلسيوم

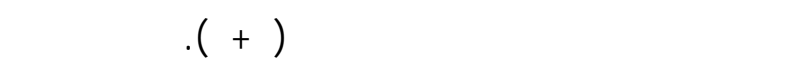

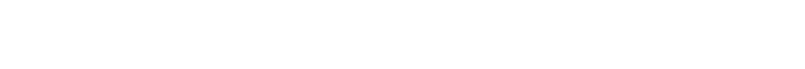

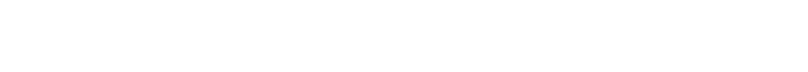

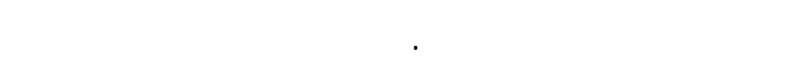

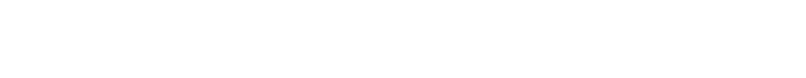

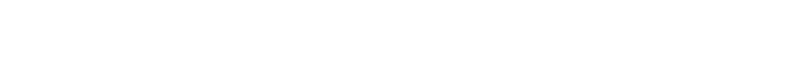
وأعله عدد من الحبوب الممتلئة فى الدالية وك ذذك أعلا م.

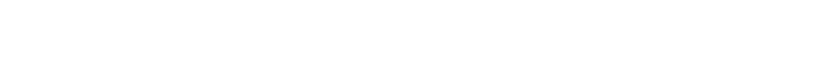

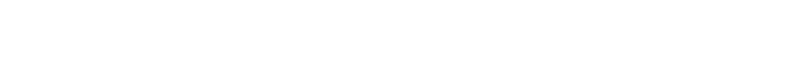

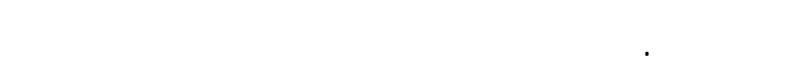

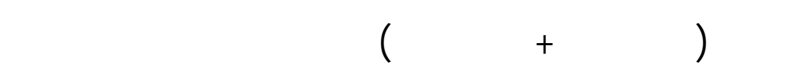

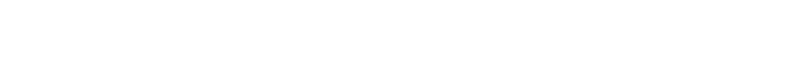

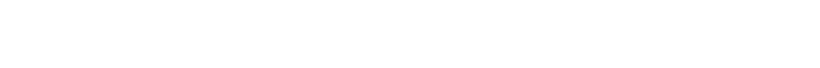

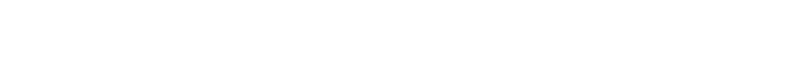

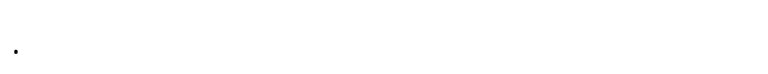

لجريت تجربتين حقليتين بالمزرء

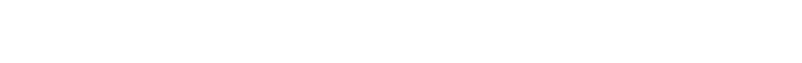

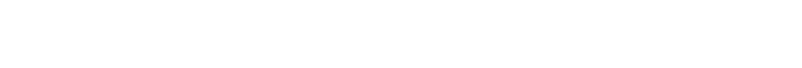
بالجبرلين والبوتلسيوم على تمهسن تحمل ملوح بة الترب ـة لثلاثة أصنف من الأرز وهي: جيزة IVV IV (جسلس لملوحة

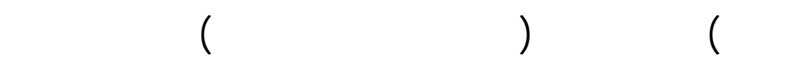

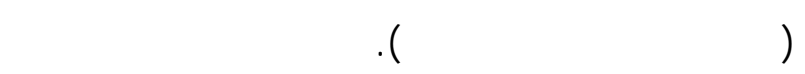
معلملات من إضلفلت البوتلسيو والجب _رلين وه م:(1)

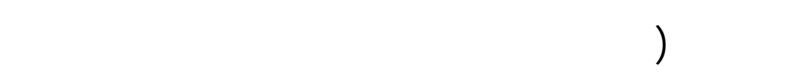

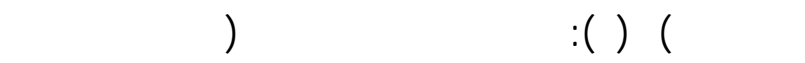

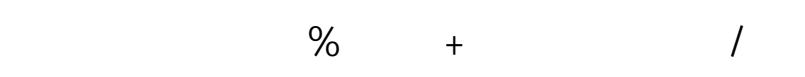

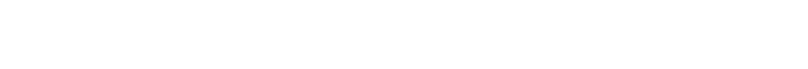

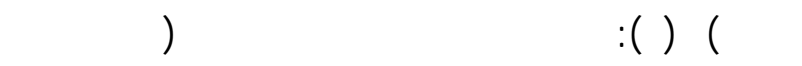

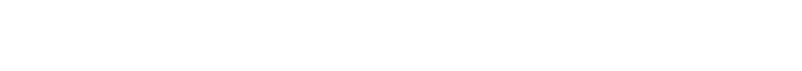

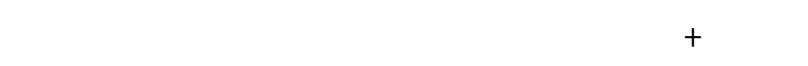

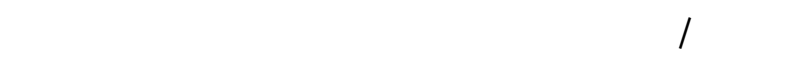


